\title{
Evolution of a Lateglacial mountain ice cap in northern Scotland
}

\author{
ANDREW FINLAYSON, NICK GOLLEDGE, TOM BRADWELL AND DEREK FABEL
}

Detailed geomorphological mapping of the Beinn Dearg massif in northern Scotland, was conducted to examine the maximum (Younger Dryas) extent, and earlier interstadial evolution, of an ice cap that existed during the Lateglacial period (14.7 - 11.7 cal. ka BP). Landform evidence indicates a plateau ice cap configuration, with radial outlet glaciers, during the Younger Dryas. The interpreted age is supported by new cosmogenic exposure ages, and previously reported interstadial sediments beyond the ice cap margin. The reconstructed Younger Dryas Beinn Dearg ice cap covered $176 \mathrm{~km}^{2}$, with its summit positioned over the western side of the massif. Area-altitude balance ratio (AABR) equilibrium line altitudes (ELAs) of $570-580 \mathrm{~m}$ were calculated for the ice cap as a whole. The empirically reconstructed ice cap is compared with recent numerical model simulations; both methods produce an ice cap with a similar configuration. However, differences are apparent in the extent of eastern and western outlets $( \pm 1-5 \mathrm{~km})$, and in the spatial variation of ELAs. Results suggest that the numerical simulation over-estimates the extent of western ice cap sectors, and under-estimates the extent of eastern ice cap sectors. We attempt to quantify these differences in terms of ice cap mass balance and assess their possible causes. Geomorphological evidence for pre-Younger Dryas ice cap configuration indicates that the Beinn Dearg massif remained an important source during earlier deglaciation. In contrast, the neighbouring Fannich mountains acted as an 'unzipping' zone, and were ice free on their northern side by the Allerød (Greenland Interstadial 1c to 1a). Deglaciation continued over western parts of the Beinn Dearg plateau, with the possibility that glaciers remained in some central and eastern catchments, prior to (Younger Dryas) ice cap (re)growth.

Andrew Finlayson (e-mail: afin@bgs.ac.uk), British Geological Survey, Edinburgh, UK and Institute of Geography, University of Edinburgh, UK; Nick Golledge (e-mail: nick.golledge@vuw.ac.nz), Antarctic Research Centre, Victoria University of Wellington, New Zealand; Tom Bradwell (e-mail: tbrad@bgs.ac.uk), British Geological Survey, Edinburgh, UK; Derek Fabel (e-mail: Derek.Fabel@ges.gla.ac.uk), Department of Geographical and Earth Sciences, University of Glasgow, UK.

Reconstructions of palaeo-, or formerly more extensive, ice masses in northwest Europe have enabled inference of past glacier mass balance and climate, and allowed the causes of ice mass fluctuations to be assessed (e.g. Ballantyne 1989; Dahl \& Nesje 1992; Carr 2001; Rea \& Evans 2007; Golledge et al. 2009; Nesje 2009). In the Scottish Highlands, the last decade has seen a renewed focus of research into the extent and behaviour of ice masses during the Lateglacial Younger Dryas (YD), or Loch Lomond Stadial (Greenland Stadial 1 (GS-1)) (12.9 - 11.7 cal. ka BP (Lowe et al. 2008))(e.g. Ballantyne 2002, 2007a; Benn \& Ballantyne 2005; Finlayson 2006; Golledge 2007; Lukas $\&$ Bradwell 2010). Key outcomes of this research have been the identification of spatial trends in equilibrium line altitudes (ELAs) and palaeoclimate inferred from glacier reconstructions (e.g. Ballantyne 2007b). More recently, these data have provided important 'targets' for numerical glacier simulations, aimed at identifying the envelope of climatic parameters, which allow growth of ice masses that best fit empirical reconstructions (Golledge et al. 2008). The use of cosmogenic 
nuclide analysis has furthered this work by allowing more reliable assessment of landform age (e.g. Everest \& Kubik 2006; Golledge et al. 2007; Fabel et al. 2010). Significantly, it has been demonstrated that a number of moraine sequences beyond the 'limits' of reconstructed Younger Dryas glaciers in northern Scotland, were formed during the warmer Lateglacial interstadial (Greenland Interstadial 1 (GI-1)) (14.7 - 12.9 cal. ka BP (Lowe et al. 2008)), requiring the existence of larger ice masses at that time (e.g. Bradwell et al. 2008; Ballantyne et al. 2009) (Fig 1.). This has opened an exciting avenue of research into behaviour of Lateglacial interstadial (GI-1) ice caps in Scotland (e.g. Stoker et al. 2009; Bradwell \& Stoker 2010; Ballantyne 2010).

Despite important advances arising from the work described above, there remain large areas in upland Britain that have not yet received detailed glacial geomorphological investigation. Thus, assessment of ice mass configuration during the YD is not complete. Furthermore, the geomorphological signature which relates to events immediately prior to the most recent (YD) glacial expansion has often been neglected. However, earlier landforms may shed light upon changes in glacier dynamics and configurations between GI-1 and the YD. Such evidence should yield important clues to whether or not significant ice masses survived throughout GI-1 (cf. Bradwell et al. 2008). This study attempts to address these issues for the Beinn Dearg massif (Figs 1, 2), and its surrounding area, in northern Scotland. Specifically, we: (i) map in detail the glacial landforms in, and surrounding, the Beinn Dearg massif; (ii) assess the age of landsystem components using existing and new dating evidence; (iii) reconstruct the approximate dimensions of the Beinn Dearg ice cap during the YD, making quantitative comparisons with recent simulations of a numerical ice sheet model (Golledge et al. 2008); and (iv) use the geomorphological evidence to elucidate behaviour of the ice cap during the GI-1 to YD transition, developing a conceptual model of mountain ice cap evolution during this period of rapid climatic adjustment.

\section{Study area}

The Beinn Dearg massif in northern Scotland forms a broad, $\sim 300 \mathrm{~km}^{2}$ upland plateau, lying to the east of Loch Broom (Fig. 1). Approximately $150 \mathrm{~km}^{2}(50 \%)$ of the massif lies over $600 \mathrm{~m}$ above sea level (a.s.l.), with the highest point, Beinn Dearg, rising to $1084 \mathrm{~m}$. The plateau is dissected by a number of steep sided, radial valleys and corries. In contrast, the neighbouring Fannich mountains, to the southwest, are characterised by narrower, sharp peaks, amongst generally lower ground, with less than $30 \%$ of the area lying above $600 \mathrm{~m}$ a.s.l. Bedrock in the region is composed mostly of Neoproterozoic metasedimentary rocks (psammites and pelites), although a broad area of gneissose granite occurs in the south-eastern corner of the Beinn Dearg massif (British Geological Survey 2004).

Glacial landforms in the area were first documented by Peach et al. $(1912,1913)$, who envisaged a final glacial stage where independent ice centres formed over prominent masses of high ground. The entire Beinn Dearg massif, and the Fannichs to the southwest, are within the limits of Charlesworth's (1955) 'Stage M', which elsewhere approximates several accepted Younger Dryas margins (Golledge 2010a). Interstadial sediments of at least Allerød (GI-1c to Gl-1a) (14.0 - 12.9 cal. ka BP (Lowe et al. 2008)) age, discovered at Loch Droma (Figs 1, 2) (Kirk \& Godwin 1963), demonstrate that it was ice free by that time. These sediments had not been modified by any 
subsequent glacier advance, and thus conflict with the association of Charlesworth's (1955) 'Stage M' with YD glacier limits in this area. Kirk \& Godwin (1963) and Kirk et al. (1966) suggested that a local glaciation of the Beinn Dearg massif (their 'Gharbhrain Stage') formed moraine complexes at Loch á Gharbhrain, and Strath Vaich and Strath Rannoch (Fig. 2), inferring it to be the local equivalent of the Loch Lomond Readvance (YD). Bennett \& Boulton (1993) also considered these localities to have been occupied by glacier ice at that time, with a separate glacier complex in the Fannich mountains (Fig. 2). However, Sissons (1977) considered lower Strath Vaich and Strath Rannoch to have been ice free during the Younger Dryas, and presented a more restricted reconstruction, consisting of thirteen independent glaciers in the Beinn Dearg massif, and a merged glacier complex sourced in the north and east facing corries of the Fannichs (Fig. 2). More recently, Reed (1988), Ballantyne (1997), and Finlayson \& Bradwell (2007) have suggested that a more extensive ice field or ice cap existed over the Beinn Dearg massif during the Younger Dryas - a configuration that is also simulated by numerical modelling experiments (e.g. Golledge et al. 2008; Golledge 2010b).

\section{Methods}

Glacial landforms in, and surrounding, the Beinn Dearg massif were digitally mapped in the field, using a ruggedized tablet PC, with a built-in GPS and ArcGIS 9.2 software. Using the GIS in the field enabled on-site interrogation of georectified digital aerial photographs, topographic maps, and NEXTMap digital surface models (DSMs), with $\sim 1 \mathrm{~m}$ vertical and $5 \mathrm{~m}$ horizontal resolution. Aerial photographs and hill shaded DSMs were also studied, both prior to and following, field investigation.

During the field mapping, boulders from a conspicuous, well-preserved moraine complex in Glen Alladale (Finlayson \& Bradwell 2007) were sampled for cosmogenic nuclide analyses (A 1, 2, 3 in Figs 3 and 4A) (Table 1). This site was chosen because it (i) was beyond the limits of previously reconstructed YD glaciers in the area (e.g. Sissons 1977; Reed 1988), and (ii) is at the opposite (northeast) side of the massif from where existing chronological control exists (Loch Droma). Samples were chiselled from the upper surfaces of two psammite boulders and one vein quartz boulder on a single ridge of the moraine complex. Skyline topography was measured in the field at $15^{\circ}$ increments, to allow calculation of topographic shielding. Samples were processed at the University of Glasgow's Centre for Geosciences cosmogenic isotope laboratory using methods adapted from Kohl \& Nishiizumi (1992), Ditchburn \& Whitehead (1994) and Child et al. (2000). Beryllium ratios were determined at the Scottish Universities Environmental Research Centre (SUERC) AMS facility.

\section{Glacial geomorphology}

The results of the geomorphological mapping are summarised in Fig. 3. Some detail is lost in reproducing the map at this scale, although more detailed sections are described below. GIS shapefiles of the landform data are available from the corresponding author. The glacial landforms in, and surrounding, the Beinn Dearg massif are described below, under geographical zones. 


\section{Northern valleys}

Discrete, down-valley limits of closely spaced, small (10-30 m wide, 2-5 m high), hummocky recessional moraines are present in Glen Douchary, Strath Mulzie, and Coire na Glasha (Fig. 3), and were noted by Kirk et al. (1966). These moraines contrast markedly with mounds farther to the north, which are more rounded, generally larger in size (many $>100 \mathrm{~m}$ width), with more gentle slopes. The abrupt transition between the two moraine types suggests a change in the characteristics of the ice mass that produced them. Lateral moraines and marginal meltwater channels continue up the valleys from the hummocky moraines, and eventually give way to debris flow-incised slopes, mantled with glacial sediment. A down-slope limit of thick talus coincides with the upper limit of thick sediment on the eastern side of Glen Douchary, and rises southward up the valley from 500 to $550 \mathrm{~m}$ a.s.l. The low-angle slopes of spurs between these valleys possess periglacial features in the form of blockfields and well-developed, relict, bouldery solifluction sheets and lobes. However, ice-moulded bedrock is abundant above the valley headwalls $(600-650 \mathrm{~m}$ a.s.l.), indicating that plateau ice fed the valleys below.

\section{Eastern valleys}

Glacial landforms in Glen Alladale were described by Finlayson \& Bradwell (2007). In lower Glen Alladale, they found an assemblage of moraine ridges trending perpendicular to the valley axis, and a large boulder-strewn, multi-crested moraine ridge complex against the eastern side of a tributary valley to the north (Fig. 4A). Together with asymmetric recessional moraine distribution, high level meltwater channels, and bouldery lateral moraines, Finlayson \& Bradwell (2007) concluded that the deposits most likely related to an outlet of an ice cap centred over the plateau to the southwest. Previous studies (e.g. Sissons 1977; Reed 1988) had only reconstructed small corrie glaciers in this vicinity, thus the site was selected for cosmogenic nuclide dating (see below).

At the eastern end of Gleann Mor, suites of recessional hummocky moraines suggest westward ice margin retreat from a down-valley limit at NH 430879 (200 m a.s.l.). The moraines can be traced up the northern valley side to a very well-preserved lateral moraine, which at $500 \mathrm{~m}$ a.s.l. merges with the plateau surface (Fig. 4B). Thus, the assemblage is consistent with that in Glen Alladale (Finlayson $\&$ Bradwell 2007), suggesting a plateau ice mass that fed into the valleys.

Suites of closely spaced, hummocky, recessional moraines, and well-preserved lateral moraines occupy the valleys flanking the Diebidale Ridge. The moraines terminate close to the eastern end of both valleys, at approximately $250 \mathrm{~m}$ a.s.l.; an end moraine ridge bounds a small loch in lower Glen Diebidale. The down-valley limits of these moraines probably indicate former glacier margins, broadly contemporaneous with those in Glen Alladale and Gleann Mor to the north, which terminate at similar altitudes. The moraines can be traced up the valleys toward an upper basin at approximately $550 \mathrm{~m}$ a.s.l. Thick peat has accumulated in the basin and glacial landforms are sparse. However, it is likely that the basin once acted as a source area for glacier ice in the valleys below, particularly given the evidence for plateau-sourced ice to the north.

\section{Southern valleys}

Landforms around the southern valleys of the Beinn Dearg massif are relatively well documented (e.g. Kirk et al. 1966; Reed 1988; Bennett \& Boulton 1993; Gordon 1993), and are briefly summarised 
here. A large ( $200 \mathrm{~m}$ wide, $800 \mathrm{~m}$ long), multi-crested, end moraine (Cnoc a' Mhoraire) with a distal outwash fan, dams Loch a' Gharbhrain (Fig. 3). It is immediately succeeded up the eastern valley side by closely-spaced, well-preserved, lateral and recessional moraines, which are generally composed of loose, sandy diamicton. The moraine probably marks a former readvance or still-stand margin, and morphologically resembles a hill-hole pair (c.f. Evans \& Benn 2001; Evans \& Wilson 2006). The Gharbhrain moraine can be traced towards a conspicuous lateral moraine approximately $2 \mathrm{~km}$ to the northwest, allowing good delineation of the former glacier snout.

A clear down-valley termination of closely spaced, hummocky, recessional moraines indicates a former glacier margin at $\sim 420 \mathrm{~m}$ a.s.l. in the Mhucarnaich valley. A sharp, lateral moraine trending up the south-western valley side from $460 \mathrm{~m}$ a.s.l. to $540 \mathrm{~m}$ a.s.l. approximates the former glacier surface. Clear down-slope limits of mature talus infer the dimensions of a source area in the corrie to the north (Fig. 4C), while ice-smoothed bedrock in the north-western col suggests former occupation by active glacier ice (Fig. 3).

A terraced outwash fan, approximately $0.4 \mathrm{~km}^{2}$ in area, occupies the mouth of Strath Vaich, originating at a cross-valley terminal moraine at $\sim 230 \mathrm{~m}$ a.s.l. Rising lateral moraines and associated meltwater channels continue north, up the valley from the terminal moraine, indicating a coherent former glacier margin. The valley floor is occupied by morainic mounds, an esker, and isolated terrace fragments which disappear a short distance up the valley from the terminal moraine. Larger, bouldery moraines, chaotic mounds, and boulder-scattered bedrock outcrops are present beyond the outwash fan, in the confluence of Strath Vaich and the Glascarnoch River, perhaps indicating a former area of in situ decay, as ice margins detached and retreated away from the confluence. Closely-spaced, hummocky, recessional moraines and lateral moraine fragments are present along the sides of Loch Vaich and a dense moraine assemblage occupies the valley head. Slopes here are affected by debris flows, which have incised sediment-mantled valley sides. Higher up the eastern valley sides, a transition (between 600 and $650 \mathrm{~m}$ a.s.l.) to relict bouldery solifluction lobes, then a summit blockfield at Beinn a' Chaisteil is apparent. This transition indicates the upper limit of the most recent episode of glacial modification.

A well-formed lateral and end moraine assemblage indicates a former glacier limit at the mouth of Strath Rannoch. Moraines and marginal meltwater channels continue up the valley, where a particularly clear lateral moraine can be traced continuously for almost $2.5 \mathrm{~km}$, up onto higher ground to the east.

\section{Western corries}

Three corries occupy the western side of the massif (marked ' $C$ ' on Fig. 3), and are characterised by relatively high (650 - $700 \mathrm{~m}$ a.s.l.) corrie floors partially surrounded by steep cliffs, but with open cols linking to the plateau. These corries were considered by Sissons (1977) and Reed (1988), to have been occupied by glaciers during the YD. Prominent boulder moraines (e.g. Fig. 4D) are present in each, terminating abruptly within $\sim 2 \mathrm{~km}$ of the corrie heads. The angular nature of the boulders suggests a rockfall source, and that blocks were transported supraglacially down the valley. Their abrupt down-valley termination provides strong evidence for glacier limits during the last phase of intense rockfall activity. Sparse glacial landforms exist in the few kilometres to the west of these boulder spreads, generally comprising isolated moraines and meltwater channels. 


\section{Central valley and plateau surface}

An approximately $16 \mathrm{~km}$-long valley, comprising Gleann Beag and Gleann Mor, dissects the plateau of the Beinn Dearg massif. The valley is occupied by numerous suites of recessional, hummocky moraines, although their presence is not continuous. Debris cones, sourced from thick glacial sediment deposited on valley flanks, are frequent, and sparse esker fragments occur on the valley floor. The head of Gleann Beag ( $\mathrm{NH285} 838$ ) is occupied by conspicuous, broad, morainic accumulations (up to $50 \mathrm{~m}$ in width), and superimposed fluted sediment, streamlined in a northeastward direction. Similar accumulations are present at up to $700 \mathrm{~m}$ a.s.l. at the head of the corrie of Loch Tuath (NH 280 823), a tributary to Gleann Beag. Here, broad mounds are fluted towards the east, and possess a flat, streamlined surface (Fig. 5), suggesting that they have been smoothed by eastward ice flow, subsequent to their initial deposition.

Plateau areas immediately above the headwalls of outlet valleys are commonly characterised by smooth, ice-moulded bedrock - most likely the consequence of increased basal abrasion under accelerating, wet-based, ice flowing steeply into the valleys. Flatter, and more central parts of the plateau do not possess such features, and in places are occupied by relict landforms, such as the preserved (possible pre-Quaternary) fluvial valley at NH 3081 (Fig. 6). Higher ground, around the western summits of Beinn Dearg, Eididh nan Clach Geala, and Seana Bhraigh are characterised by mature periglacial features, such as blockfields and relict boulder sheets and lobes. Where such features occur above, but in close proximity to, glacially modified terrain (characterised, for example, by ice-smoothed bedrock or moraines), upper limits of the most recent phase of glacial alteration may be inferred.

\section{Loch Droma and the northern Fannichs}

Large bouldery moraines, sparse kettle holes, and meltwater channels extend west-north-westward down the valley from Loch Droma; these landforms document ice margin retreat back towards Loch Droma. In Coir' a Mhadaidh, $100 \mathrm{~m}$-wide mounds arc up into a col, and can be traced back down valley towards lower ground (Fig. 3). At NH 237 749, a section revealing sheared, laminated, fine sands may indicate former ponding against an active ice margin which retreated out of the valley towards the northeast. A complex palimpsest moraine assemblage is present in the Ghiuthais valley (Figs 3,7 ). Here broad, cross-valley moraine ridges that arc up into the valley, are overprinted in places by an assemblage of smaller, bouldery moraines, flutes, and meltwater channels, which descend down the valley to the northeast. The broad moraines suggest ice margin retreat out of the valley towards the north. In contrast, the latter morainic assemblage suggests an ice advance from high ground to the south, terminating at approximately $320 \mathrm{~m}$ a.s.l.

\section{Chronology}

Combining geomorphological evidence to make inferences about former glacier configurations requires an assessment of landform age. Loch Droma is a well-known site where sediments of preYD age were discovered during excavations for a dam embankment (Kirk \& Godwin 1963). A single, bulk sample from the base of an organic layer in the profile yielded a radiocarbon age of $12810 \pm 155$

${ }^{14} \mathrm{C}$ yrs B.P (15 456 \pm 900 cal. a B.P. $(2 \sigma)$ (Calib 6.0, Stuvier \& Reimer, 2010). However, Kirk \& Goodwin 
(1963) stated that the radiocarbon age is probably at least 1000 years too old, and may have been affected by incorporation of older material, or by hard water error in an open water environment. Based on stratigraphic and pollen analyses Kirk \& Godwin (1963) suggest that the sediments are of Allerød age (GI-1c to GI-1a: $14-12.9$ cal. ka BP). Thus landforms to the west of Loch Droma, and those in the northern Fannichs indicative of northward ice margin retreat, are considered to be older than 12.9 cal. ka BP.

Three boulders sampled from the Glen Alladale moraine complex (Fig. 4A) (Tables 1, 2), yielded overlapping exposure ages that are strongly suggestive of a YD age of deposition. The oldest sample, A2 (12.9 $\pm 1.6-12.4 \pm 1.3 \mathrm{ka} \mathrm{BP})$, suggests deposition at, or close to, the start of the YD. Limited, localised moraine degradation may have occurred in the vicinity of sample $A 3$, closest to the moraine edge (Fig. 4A), giving an analytical uncertainty that does not overlap with the oldest sample at $1 \sigma$ (Table 2), and a slightly younger minimum exposure age $(11.0 \pm 1.4-10.6 \pm 1.0 \mathrm{ka} \mathrm{BP})$. Importantly, the moraine complex is indicative of non-topographically constrained ice flow (Finlayson \& Bradwell 2007), thus suggesting a plateau ice source, and ice cap-style configuration (c.f. Golledge 2007) at the time of deposition.

Landforms can also be assessed on a morphostratigraphical basis (c.f. Lukas 2006), whereby particular landsystem components provide clues to landform age (e.g. Ballantyne 1989, 2002, 2007a; Benn \& Ballantyne 2005; Finlayson 2006; Finlayson \& Bradwell 2007; Lukas \& Bradwell 2010). Suites of closely-spaced, 'hummocky', recessional, moraines are commonly, although not always (e.g. Clapperton et al. 1975; Everest \& Kubik 2006), observed within the limits of former YD glaciers which have been dated by other evidence (e.g. Walker et al. 1988; Ballantyne 1989). Their presence in several valleys in the Beinn Dearg massif suggests the possibility of a YD age, an intepretation consistent with the cosmogenic exposure ages discussed above. Mature periglacial landforms can also be useful indicators of age. The last period of intense periglacial activity in upland Britain was the YD (Ballantyne \& Harris 1994). The distribution of mature, relict, periglacial forms over upper parts of the Beinn Dearg massif may thus indicate areas that were not protected, or modified by, glacier ice at that time.

Landform overprinting also enables interpretation of relative age. The thick sediment mounds at the head of Gleann Beag and by Loch Tuath (Fig. 5), are fluted and, in places, planed off on their surfaces, suggesting that a later glacial event modified the mounds following their initial deposition. Our interpretation is that these mounds were originally deposited by eastward ice cap retreat and thinning (see below), allowing sediment to accumulate between the ice margin and reverse slope, prior to subsequent ice cap thickening, overriding and streamlining. Hättestrand et al. (2008) have reported morphologically similar features, termed 'cirque infills' on the Kola Peninsula in Russia. Abundant sources for the debris would have existed during ice cap thinning and retreat, including: rockfall, fluvial transport from the upper valley, and debris flows / fluvial transport from valley sides and ice margin. Smoothing and fluting of the mounds presumably occurred during subsequent (YD) glacier overriding. Similarly, moraine cross-cutting in the Ghiuthais valley of the northern Fannichs (Fig. 7), suggests that an initial phase of ice margin retreat towards the north was followed by renewed advance of ice from high ground in the south. The most likely period for this renewed advance would be the YD. 


\section{The Younger Dryas Beinn Dearg ice cap}

\section{Reconstruction}

Collectively, the evidence presented above allows an empirically-based, three-dimensional representation of the ice cap that occupied the Beinn Dearg massif during the YD (Figs 8A, 8B). The reconstruction is a synthesis based on the cumulative landform evidence, and thus represents the integrated maximum glacier extent in all individual outlets. However, it cannot be demonstrated that all outlet glaciers occupied their maximum positions simultaneously. Ice margins and surface contours were reconstructed following procedures outlined in previous studies (e.g. Sissons 1974; Ballantyne 1989, 2002, 2007a; Benn \& Ballantyne 2005). Over high ground, such as the western summits of Beinn Dearg and Eididh nan Clach Geala, zones of mature periglacial deposits are considered not to have been covered by active ice, although a non-erosive, cold-based ice cover cannot be ruled out (e.g. Gordon et al. 1987; Gellatly et al. 1988; McDougall 2001; Rea \& Evans 2003). The preserved (possible pre-Quaternary) fluvial valley (Fig. 6) on the plateau surface is considered to have been covered by cold-based ice. This is supported by the distribution of glaciallymodified landforms that show an outwardly radial pattern in the vicinity. The Beinn Dearg ice cap, as reconstructed here, has a total area of $176.2 \mathrm{~km}^{2}$. One small additional $\left(2.74 \mathrm{~km}^{2}\right)$ independent glacier (the Mhucarnaich glacier) is also reconstructed on the south-western corner of the massif.

The reconstruction is based solely on geomorphological evidence. To test the theoretical range of basal shear stresses required by the reconstruction, the 'Profiler v.2' spreadsheet of Benn \& Hulton (2010) was used. The glacier reconstruction for Glen Douchary was used, as it includes the widest range of reconstructed glacier surface slopes (from a relatively 'flat' plateau area to a zone where steeply flowing ice fed into the valley below). The glacier profile and shear stresses, assuming perfectly plastic ice rheology (c.f Benn \& Hulton 2010) are shown in Figure 9. Low basal shear stresses (tending towards zero) were calculated on the plateau, consistent with observations of landform preservation over parts of the plateau. Shear stresses increased (up to $250 \mathrm{kPa}$ ) where ice accelerated, flowing steeply into the valley below (possibly as an ice fall). This is also consistent with landform evidence, where moulded bedrock was observed immediately above the valley headwall. In the valley, shear stress remained constant at approximately $50 \mathrm{kPa}$. A slight reduction in reconstructed shear stress over $1.5 \mathrm{~km}$ at the glacier margin suggests that basal sliding or sediment deformation may have occurred.

Equilibrium line altitudes (ELAs)

Equilibrium line altitudes (ELAs) on ice masses indicate theoretical lines where annual accumulation and ablation are balanced. Mass balance studies on modern ice masses have shown that ELAs are strongly linked to regional ablation-season temperature and accumulation-season precipitation, providing a link between glaciers and climate. For comparison with data from elsewhere in Scotland, we present ELAs calculated by the area weighted mean altitude (AWMA), accumulation area ratio (AAR), and area altitude balance ratio (AABR) methods (Table 3). The AWMA method assumes identical, linear accumulation and ablation gradients, and thus tends to overestimate ELAs, as ablation gradients are often steeper in reality. The AAR method can account for net ablation occurring over a smaller proportion of an ice mass, but does not consider ice mass hypsometry (see Osmaston 2005 for review). AABR methods are generally assessed to be more reliable (Ballantyne 
2002; Benn \& Ballantyne 2005; Osmaston 2005), and incorporate an assumed balance ratio, defined as ablation gradient/accumulation gradient (thus a balance ratio of 1 yields an ELA equivalent to that of the AWMA method). Previous Scottish studies use balance ratios of between 1.67 and 2.0 (e.g. Ballantyne, 2002; Benn \& Ballantyne 2005; Finlayson 2006; Lukas \& Bradwell 2010) - a range that includes $A A B R s$ considered to be representative of modern mid-latitude maritime glaciers (Rea 2009). Using these values the AABR method yields ELAs of between $570 \mathrm{~m}$ and $580 \mathrm{~m}$ for the reconstructed Beinn Dearg ice cap as a whole. As the ice cap was drained radially, its overall ELA gives a good approximation of the regional temperature-precipitation dependent ELA, independent of the effects of deflation and snow drifting (Dahl \& Nesje 1992). In order to evaluate spatial variations in ELA within the ice cap, it was divided into sectors based upon former ice flow direction (Fig. 8B). A general eastward decline in ELA across the ice cap is evident - a characteristic common to reconstructed YD ice masses in Scotland (e.g. Ballantyne 1989, 2002; Benn \& Ballantyne 2005). The eastward decline in ELAs is probably a result of eastward snow redistribution across the ice cap by strong westerly winds during the YD.

Previous studies have used glacier reconstructions to make palaeoclimatic inferences, based upon relationships between total precipitation and summer temperature at the ELA (e.g. Benn \& Ballantyne 2005; Finlayson 2006; Lukas and Bradwell 2010). These studies have favoured a nonlinear relationship, derived from a global sample of modern glaciers by Ohmura et al. (1992), expressed as:

$P=9 T_{a}^{2}+296 T_{a}+645$

where $P$ is the sum of winter accumulation $\left(b_{w}\right)$ plus summer precipitation at the ELA, and $T_{\alpha}$ is the mean ablation season air temperature at the ELA (usually derived from biological proxies and extrapolated to the location under investigation). However, recent studies by Golledge (2008) and Golledge et al. (2010) have shown that use of such a global dataset neglects the regional influence of seasonality upon former Scottish ice masses during the YD, and may have resulted in over-estimates of palaeoprecipitation. As a result, Golledge et al. (2010) used numerical model output to propose an alternative precipitation-temperature function specific to the Scottish YD environment. The alternative function allows for an annual temperature range (mean July $T$ - mean Jan $T=30^{\circ} \mathrm{C}$ ) that was three times greater than today, and so is more aligned with evidence from some palaeoclimatic proxies (e.g. Atkinson et al. 1987; Isarin et al. 1998; Witte et al. 1998; Lie \& Paasche 2006):

$$
P=S\left(14.2 T_{a}^{2}+248.2 T_{a}+213.5\right)
$$

$S$ is a scaling coefficient allowing for seasonality in precipitation $(S=1$ for neutral precipitation seasonality where daily precipitation $=1 / 365 \times$ total annual precipitation; $S=1.4$ for summer dominated precipitation; and $S=0.8$ for winter dominated precipitation; Golledge et al. 2010). It is also useful to consider a function that assumes a modern maritime annual temperature range (mean July $T$ - mean Jan $T=10^{\circ} \mathrm{C}$; Golledge 2008), which is derived from the original modelling experiments presented by Golledge et al. (2008):

$P=S\left(25.3 T_{a}^{2}-4.7 T_{a}+17.9\right)$ 
Using an ablation-season sea level palaeo-temperature of $6.38^{\circ} \mathrm{C}$ (Golledge 2008) for the coldest part of the YD in northwest Scotland, and an assumed lapse rate of $0.006^{\circ} \mathrm{C} \mathrm{m}^{-1}$, palaeo-precipitation values at the ELA can be calculated using equations 1, 2, and 3 (Table 4). A variety of climatic regimes are represented, clearly highlighting the range of scenarios for seasonality that could have resulted in a mass balance, permitting the existence of the YD Beinn Dearg ice cap.

\section{Comparison with model simulations}

Numerical modelling experiments aimed at simulating a 'best fit' to accepted YD glacier limits in Scotland (Golledge et al. 2008), produced a YD ice cap over the Beinn Dearg massif with a similar overall configuration to the empirically reconstructed ice cap presented here (Fig. 10), although key differences are apparent, as discussed below. The numerical simulation assumed initial ice-free conditions, and was forced by a GRIP-pattern temperature depression $\left(10^{\circ} \mathrm{C}\right.$ lowering of annual temperature at YD maximum). Seasonality was considered to follow present (maritime) annual temperature ranges, and modern precipitation values were invoked over western Scotland, but with $60 \%$ northward and $80 \%$ eastward reductions (see Golledge et al. 2008 for more discussion). In subsequent experiments, Golledge et al. (2010) and Golledge (2010b) found that similar modelled glacier configurations across Scotland could equally be produced with doubled or trebled seasonality, combined with reduced total precipitation, and more relaxed precipitation gradients; thus demonstrating that different climatic regimes can produce similar overall ice mass dimensions, albeit with different glaciological conditions.

For the purposes of this discussion, comparisons are made with the simulation of Golledge et al. $(2008,2009)$, which is most fully described. The numerical simulation produced an overall ice cap configuration, drained radially by valley outlets, with a summit ( $900 \mathrm{~m}$ a.s.l.) in the west, and glacier ice in the elevated basin in the south-eastern corner of the massif. A similar overall configuration is empirically reconstructed here. The numerical model simulates negligible basal velocities and low (2 to $-4.5^{\circ} \mathrm{C}$ ) basal temperatures over much of the plateau (Golledge et al. 2009), with the exception of 'drawdown' zones which feed valley outlet glaciers. This is also consistent with the empirical evidence. Key differences are that the numerical simulation produced more extensive western glacier limits and less extensive eastern glacier limits (generally $\pm 1-5 \mathrm{~km}$ ). We now discuss some possible reasons for these discrepancies.

Possible underestimates in the empirical reconstruction for western areas may arise due to preferential production/preservation of landforms during latter parts of the stadial. In eastern outlets of the Beinn Dearg range, over-estimation using empirical evidence may occur by mistakenly assigning a YD age to older landforms. However, the available dating evidence suggests that the empirical reconstruction is correct. Since the numerically modelled ice cap impinges upon Loch Droma (known to have been ice-free during the YD) in the southwest, and does not reach the dated limits in Glen Alladale (Figs 3, 4A)(Table 3), it is considered to be in error in those areas. Although increased dating control is desirable, the generalised conclusion made for the Beinn Dearg range, is that the numerical model over-predicts western glacier extent, and under-predicts eastern glacier extent. Golledge et al. (2008) indicate that accumulation in the model does not take into account mass redistribution by wind, and suggest that this may introduce a degree of error. As the overall configuration and catchments of the empirically reconstructed and modelled ice caps are similar (Fig. 10), it is useful to compare the spatial variations in their ELAs (Table 5). Modelled ELAs are 
obtained by identifying cells in glacier flow lines where net mass balance $=0$. A general eastward rise in ELA is apparent for the numerical simulation - largely a consequence of the precipitation gradients that were imposed to fit the regional (Scotland wide) ice distribution. In contrast, an eastward ELA decline is calculated across the ice cap from the empirical reconstruction. This supports the contention that eastward wind redistribution influenced the ice cap's mass balance at a local scale. To gauge the required mass transfer $\left(\delta b_{w}\right)$ that would account for the ELA differences $(\Delta h)$, the relation given by Hooke (2005) can be used:

$$
\frac{\partial b_{w}}{\partial z} \Delta h+\delta b_{w}=\frac{\mathbf{T}}{L}\left[\frac{\partial R}{\partial z} \Delta h+\delta R+\gamma\left(\frac{\partial T_{a}}{\partial z} \Delta h+\delta T_{a}\right)\right]
$$

$\partial b_{w} / \Delta z$ is the winter balance-elevation gradient $\left(\mathrm{kg} \mathrm{m}^{-2} \mathrm{~m}^{-1}\right) . \mathbf{T}$ is the length of the melt season in days ( 150 days close to the former ELA elevation, derived from an annual sinusoidal temperature variability curve (Golledge 2008)), $L$ is the latent heat of fusion of ice $\left(334 \mathrm{~kJ} \mathrm{~kg}^{-1}\right), R$ is net radiation (MJ m $\left.\mathrm{m}^{-2} \mathrm{~d}^{-1}\right), \gamma$ is a constant of proportionality (suggested to be $\sim 1.7 \mathrm{MJ} \mathrm{m}^{-2} \mathrm{~d}^{-1} \mathrm{~K}^{-1}$, for glacier ice (Kuhn (1989)), and $T_{a}$ is mean ablation season air temperature. Based on modern data from northwest Scotland, Ballantyne (2002) calculated a proportional increase in precipitation of $5.8 \%$ for every $100 \mathrm{~m}$ of elevation gain. Since the numerical model being compared here is based on a $10^{\circ} \mathrm{C}$ annual temperature range, combining the neutral-type $P$ value of eq. 3 (Table 4) (adjusted to represent winter balance over $\sim 215$ days) with Ballantyne's (2002) precipitation gradient, allows a winter balance-elevation gradient of $0.8 \mathrm{~mm} \mathrm{~m}^{-1}$, or $0.8 \mathrm{~kg} \mathrm{~m}^{-2} \mathrm{~m}^{-1}$ to be approximated. Assuming that $\Delta h$ is not due to differences in $R$ or $T_{a}(\delta R=\delta T a=0)$, and that $\partial R / \partial z=0$ (as radiation input does not vary significantly with elevation (Hooke 2005)), equation 4 can be solved to give $\delta b_{w}$ values that could account for the mismatch between modelled and empirically reconstructed ELAs (Table $5)$.

Attributing the required change in $\delta b_{w}$ solely to wind redistribution, would require $\sim 36 \%$ of winter snowfall to be stripped from catchments of the exposed western corries. The similarly exposed northwest sector, and relatively less exposed southwest sector, would have to lose $\sim 19 \%$ and $\sim 2 \%$ of their winter snowfall, respectively. The north-eastern and south-eastern sectors of the ice cap would both need to gain an additional $\sim 15 \%$ to their winter snowfall from wind redistribution. Further work involving snow redistribution modelling is desirable in order to build upon these initial simple comparisons. However, the above discussion highlights the potential importance of wind redistribution when modelling ice caps at a more local scale.

A further source of error that may have contributed to the mismatches in eastern glacier extents is the possible survival of glaciers throughout the interstadial in eastern catchments. Although difficult to quantify, any surviving glaciers would have become incorporated within the ice cap that re-grew during the YD. However, glacier survival would have become relatively less important if the ice cap began to approach equilibrium.

\section{Ice cap retreat prior to Younger Dryas readvance}


Using moraines to approximate former ice-marginal positions, retreat of the Beinn Dearg ice mass prior to the YD can be partially reconstructed (Fig. 11). Given the location of these palaeo-ice fronts (inside moraines of Gl-1 age, see Fig. 1), they are considered to represent ice cap retreat during GI-1. Landform evidence from the north, west, and south suggests ice margin retreat back towards the Beinn Dearg massif, indicating that it acted as an important source area at that time. In contrast, ice margin retreat in the northern Fannich mountains was out of the valleys (away from local high ground) towards the Beinn Dearg massif. This demonstrates that the limited proportion of high ground in the Fannich mountains (characterised by sharp summits, with little plateau area), was insufficient to sustain glacier ice in those northern valleys throughout $\mathrm{Gl}-1$, and suggests that the Fannich mountains may have acted as an 'unzipping' corridor during deglaciation. An important inference is that valleys of the northern Fannich mountains had completely deglaciated by the Allerød (GI-1a- GI-1c) (when ice-free conditions are suggested by the Loch Droma sediments), and that any YD glacier growth in the northern Fannichs (e.g. Sissons 1977; Bennett \& Boulton 1993) was therefore from initial ice-free conditions.

The large, streamlined sediment mounds present in upper valleys in western parts of the Beinn Dearg massif are of importance (Fig. 5). They are interpreted here as primarily ice marginal accumulations, formed as sediment banked up between ice margins and reverse slopes during retreat across the Beinn Dearg massif, prior to subsequent YD ice cap thickening and streamlining. Interpreted in this way, they demonstrate that active ice eventually thinned to below the height of the plateau in the western massif during GI-1, and that glacier source areas during the latter part of the interstadial ( 13.5 cal. ka BP) were towards central or eastern parts of the massif.

This interpreted pattern of late-stage ice margin decay towards the east, contrasts to the modelled YD ice build up pattern (centred on the watershed in the west), where an ice-free interstadial is assumed (Golledge et al. 2008). We speculate that glacier ice persistence in the Beinn Dearg massif would have been most likely in high, or shaded, central and eastern localities, where interstadial mass turnover and response times might have been slowest. Had glacier ice survived throughout GI1 in those places, it could then have become incorporated within the ice cap that re-grew during the YD - providing a possible additional contribution to explaining the discrepancy between the empirical reconstruction and numerical simulation in the east. The oldest exposure age from the Glen Alladale moraine (Table 2) suggests deposition near the start of the YD, lending some support to the concept of glacier ice survival in the east.

\section{A conceptual model of Lateglacial mountain ice cap evolution in northern Scotland}

In synthesising the above, it is useful to present a simple conceptual model of ice cap evolution in the region during the GI-1 to YD transition of the Lateglacial (Fig. 12). Ice cap thinning, and marginal retreat towards key source areas, such as the Beinn Dearg massif, probably occurred during GI-1, following dated ice sheet oscillations along the Scottish north-western seaboard (Bradwell et al. 2008; Ballantyne et al. 2009) (Fig. 1). Ranges, such as the Fannich mountains, with little accumulation area, acted as 'unzipping' zones, accompanied, in places, by deposition of broad ice marginal landforms, which arc into their valleys (Fig. 12A). Loch Droma, became ice-free by the 
Allerød (GI-1a to GI-1c) (within error of the dated ice sheet limit in Wester Ross, c 14 cal. ka BP (Ballantyne et al. 2009)), suggesting relatively rapid ice margin retreat from low-lying coastal areas. Reduced sea ice cover would have allowed near-modern precipitation values at that time, enhancing mass turnover, melt, and debris evacuation, and leading to localised formation of large morainic accumulations and ice-contact glaciofluvial topography. As the ice mass thinned over the Beinn Dearg massif, plateau areas in the west became ice-free first (Fig. 12B), with the possibility that more slowly responding glacier ice survived in less maritime, eastern parts of the massif. At that time the northern Fannich mountains had probably completely deglaciated. It is not known how much ice survived in the Beinn Dearg massif during late stages of GI-1. However, cooler temperatures at the end of GI-1 and during the YD, resulted in re-growth of the Beinn Dearg ice cap, with the summit now positioned over the western part of the massif (Fig. 12C). Strong westerly winds (e.g. Brauer et al. 2008) probably redistributed snow from western to eastern parts of the ice cap, resulting in relative lowering of ELAs in the east. Lateral extent of the ice cap was more limited compared to earlier stages of the preceding GI-1. In the northern Fannich mountains glaciers probably grew afresh. Preservation of landforms interpreted as pre-YD in age, combined with the profile of the ice cap, suggests that motion was predominantly by internal deformation over the plateau, and locally basal sliding (with perhaps some bed deformation) in outlet areas (c.f. Golledge et al. 2009). Retreat of the YD ice cap left regular, closely-spaced recessional moraine assemblages in many outlet valleys, indicative of active, oscillatory retreat (e.g. Benn \& Lukas 2006; Ballantyne 2007b) or high mass loss, due to enhanced surface melting supplying ice-marginal debris flows during retreat (e.g. Golledge 2010b). The resultant landscape (Fig. 12D) now encompasses both regular recessional moraine assemblages and palimpsest assemblages, indicative of changes in ice mass configuration during the Lateglacial period. Testing this model would enhance our understanding of glacier dynamics during the rapid environmental changes characteristic of the Lateglacial period, and provide further insight into ice cap response during transitional warm phases, such as GI-1. We propose that future work should include targeting eastern margins of former Scottish ice caps for cosmogenic exposure dating, in order to refine empirical reconstructions and guide numerical glacier simulations of the Lateglacial period.

\section{Conclusions}

Detailed geomorphological mapping of the Beinn Dearg massif in northern Scotland, has enabled reconstruction of the evolution of a former ice cap during the Lateglacial period ( $c$ 14.7-11.7 cal. ka cal BP). The age of glacial landforms is constrained by previously recorded interstadial sediments at Loch Droma (Kirk \& Godwin 1963), new cosmogenic exposure ages from a north-eastern outlet of the Beinn Dearg massif, and morphostratigraphic assessment. Based on empirical evidence, a 176 $\mathrm{km}^{2}$ ice cap is reconstructed over the Beinn Dearg massif during the YD. The ice cap was centred over the western side of the Beinn Dearg massif and ELAs (AABR method) are calculated to have been between $\sim 570$ and $580 \mathrm{~m}$ a.s.l. over the ice cap as a whole.

The empirical reconstruction bears many similarities to a modelled ice cap produced in a recent numerical simulation of YD glaciation in Scotland (Golledge et al. 2008). However, differences are apparent, predominantly in the form of glacier ice extent in western and eastern outlets. Comparison of empirically reconstructed and modelled ELAs for different ice cap sectors reveals contrasting patterns. As the numerical model did not allow for wind redistribution, one explanation for these contrasts is that winter balance over western sectors was reduced $(2 \%-36 \%$ loss 
depending on exposure) by deflation. Eastern sectors could have gained an additional $15 \%$ to their winter snowfall from deposition of blown snow. Differences in eastern glacier extent may also be complicated by the assumption of initial ice-free conditions in model runs. Significantly, however, both empirical and numerical reconstructions concur on the style and scale of glaciation in this area.

Landform evidence indicative of ice cap configuration prior to the Younger Dryas readvance suggests that the Beinn Dearg massif was an important source during interstadial ice cap retreat. In contrast, the neighbouring Fannich mountains acted as an 'unzipping' zone, and had probably completely deglaciated on their northern side by the Allerød ( $G I 1 c-1 a)$. As the ice cap thinned over the Beinn Dearg massif, plateau areas in the west became ice-free, with the possibility that more slowly responding glacier ice survived in sheltered, central and eastern parts of the massif. Renewed cooling in the YD enabled regrowth of glaciers in the northern Fannich mountains from ice-free conditions, and growth of a thicker ice cap over the Beinn Dearg massif.

Acknowledgements. - Cosmogenic nuclide analyses were supported by a BGS-University collaboration (BUFI) award (E2152S60), made to NG and DF. Colin Ballantyne is thanked for his encouragement of this work. Maarten Krabbendam took the photographs in Figure 8. He and Jon Merritt kindly commented on an earlier version of this manuscript. Doug Benn and Atle Nesje are thanked for their reviews which lead to improvements of this paper. This paper is published with the permission of the Executive Director of the British Geological Survey (NERC). 


\section{References}

Atkinson, T.C., Briffa, K.R. \& Coope, G.R. 1987: Seasonal temperatures in Britain during the past 22000 years, reconstructed using beetle remains. Nature 325, 587-592.

Balco, G., Stone, J.O., Lifton, N.A. \& Dunai, T.J. 2008: A complete and easily accessible means of calculating surface exposure ages or erosion rates from ${ }^{10} \mathrm{Be}$ and ${ }^{26} \mathrm{Al}$ measurements. Quaternary Geochronology 3, 174195.

Ballantyne, C.K. 1989: The Loch Lomond Readvance on the Isle of Skye, Scotland: glacier reconstruction and palaeoclimatic implications. Journal of Quaternary Science 4, 95-108.

Ballantyne, C.K. 1997: Periglacial trimlines in the Scottish Highlands. Quaternary International 38/39, 119-136.

Ballantyne, C.K. 2002: The Loch Lomond Readvance on the Isle of Mull, Scotland: glacier reconstruction and palaeoclimatic implications. Journal of Quaternary Science 17, 759-771.

Ballantyne, C.K. 2007a: The Loch Lomond Readvance on north Arran, Scotland: glacier reconstruction and palaeoclimatic implications. Journal of Quaternary Science 22, 343-359.

Ballantyne, C.K. 2007b: Loch Lomond Stadial glaciers in North Harris, Outer Hebrides, North-West Scotland: glacier reconstruction and palaeoclimatic implications. Quaternary Science Reviews 26, 3134-3149.

Ballantyne, C.K. 2010: Extent and deglacial chronology of the last British-Irish Ice Sheet: implications of exposure dating using cosmogenic isotopes. Journal of Quaternary Science 25, 515-534.

Ballantyne, C. K. \& Harris, C. 1994: The Periglaciation of Great Britain. 339 pp. Cambridge University Press, Cambridge.

Ballantyne, C.K., Schnabel, C. \& Xu, S. 2009: Readvance of the last British-Irish Ice Sheet during Greenland Interstade 1 (GI-1): the Wester Ross Readvance, NW Scotland. Quaternary Science Reviews 28, 783-789.

Benn, D.I. \& Ballantyne, C.K. 2005: Palaeoclimatic reconstruction from Loch Lomond Readvance glaciers in the West Drumochter Hills, Scotland. Journal of Quaternary Science 20, 577-592.

Benn, D.I. \& Lukas, S. 2006: Younger Dryas glacial landsystems in North West Scotland: An assessment of modern analogues and palaeoclimatic implications. Quaternary Science Reviews 25, 2390-2408.

Benn, D.I. \& Hulton, N.R.J. 2010: An Excel $^{\mathrm{TM}}$ spreadsheet program for reconstructing the surface profile of former mountain glaciers and ice caps. Computers and Geosciences 36, 605-610.

Bennett, M.R. \& Boulton, G.S. 1993: Deglaciation of the Younger Dryas or Loch Lomond Stadial ice-field in the northern Highlands, Scotland. Journal of Quaternary Science 8, 133-145.

Bradwell, T., Fabel, D., Stoker, M., Mathers, H., McHargue, L. \& Howe, J. 2008: Ice caps existed throughout the Lateglacial Interstadial in northern Scotland. Journal of Quaternary Science 23, 401-407. 
Bradwell, T. \& Stoker, M.S. 2010: Ice sheet glaciation of NW Scotland. In: Lukas, S. \& Bradwell, T. (eds). The Quaternary of Western Sutherland and adjacent areas: Field Guide, 39-46. Quaternary Research Association, London.

Brauer, A., Haug, G.H., Dulski, P., Sigman, D.M. \& Negendank, J.F.W. 2008: An abrupt wind shift in western Europe at the onset of the Younger Dryas cold period. Nature Geoscience 1, 520-523.

British Geological Survey 2004: Ben Wyvis. Scotland Sheet 93W. Bedrock \& Superficial Deposits. 1:50, 000. British Geological Survey, Keyworth, Nottingham.

Carr, S.J. 2001: A glaciological approach for the discrimination of Loch Lomond Stadial glacial landforms in the Brecon Beacons, South Wales. Proceedings of the Geologists' Association 112, 253-262.

Charlesworth JK. 1955: Late-glacial history of the Highlands and Islands of Scotland. Transactions of the Royal Society of Edinburgh 62, 769-928.

Child, D., Elliott, G., Mifsud, C., Smith, A.M. \& Fink, D. 2000: Sample processing for earth science studies at ANTARES. Nuclear Instruments and Methods in Physics Research B 172, 856-860.

Clapperton, C.M., Gunson, A.R. \& Sugden, D.E. 1975: Loch Lomond Readvance in the eastern Cairngorms. Nature 253, 710-712.

Clark, C.D., Evans, D.J.A., Khatwa, A., Bradwell, T., Jordan, C.J., Marsh, S.H., Mitchell, W.A. \& Bateman, M.D. 2004: Map and GIS database of landforms and features related to the last British Ice Sheet. Boreas 33, 359375.

Dahl, S.O. \& Nesje, A. 1992: Palaeoclimatic implications based on equilibrium-line-altitude depressions of reconstructed Younger Dryas and Holocene cirque glaciers in inner Nordfjord, western Norway. Palaeogeography, Palaeoclimatology, Palaeoecology 94, 87-97.

Desilets, D. \& Zreda, M., 2003: Spatial and temporal distribution of secondary cosmic-ray nucleon intensities and applications to in-situ cosmogenic dating. Earth and Planetary Science Letters 206, 21-42.

Desilets, D., Zreda, M. \& Prabu, T. 2006: Extended scaling factors for in situ cosmogenic nuclides: new measurements at low latitude. Earth and Planetary Science Letters 246, 265-276.

Ditchburn, R.G. \& Whitehead, N.E. 1994: The separation of ${ }^{10}$ Be from silicates. In 3rd Workshop of the South Pacific Environmental Radioactivity Association, 4-7.

Dunai, T.J. 2001: Influence of secular variation of the geomagnetic field on production rates of in situ produced cosmogenic nuclides. Earth and Planetary Science Letters 193, 197-212.

Dunne, J., Elmore, D. \& Muzikar, P., 1999: Scaling factors for the rates of production of cosmogenic nuclides for geometric shielding and attenuation at depth on sloped surfaces. Geomorphology 27, 3-11.

Evans, D.J.A. \& Benn, D.I. 2001: Earth's giant bulldozers. Geography Review 14, 22-33.

Evans, D.J.A. \& Wilson, S.B. 2006: Scottish Landform Example 39: The Lake of Menteith Glaciotectonic hill-hole pair. Scottish Geographical Journal 122, 352-364.

Everest, J. \& Kubik, P. 2006: The deglaciation of eastern Scotland: cosmogenic ${ }^{10}$ Be evidence for a Lateglacial stillstand. Journal of Quaternary Science 21, 95-104. 
Fabel, D., Small, D., Miguens-Rodriguez, M. \& Freeman, S. 2010: Cosmogenic nuclide exposure ages from the 'Parallel Roads' of Glen Roy, Scotland. Journal of Quaternary Science 25, 597-603.

Finlayson, A. 2006: Glacial geomorphology of the Creag Meagaidh massif, western Grampian Highlands: implications for local glaciations and palaeoclimate during the Loch Lomomd Stadial. Scottish Geographical Journal 122, 293-307.

Finlayson, A. \& Bradwell, T. 2007: Evidence for Loch Lomond Stadial ice cap glaciation of the Beinn Dearg Massif, Northern Scotland. Quaternary Newsletter 113, 10-17.

Gellatly, A.F., Gordon, J.E., Whalley, W.B. \& Hansom, J.D. 1988: Thermal regime and geomorphology of plateau ice caps in northern Norway: Observations and implications. Geology 16, 983-986.

Golledge, N.R. 2007: An ice cap landsystem for palaeoglaciological reconstructions: characterizing the Younger Dryas in western Scotland. Quaternary Science Reviews 26, 213-229.

Golledge, N.R. 2008: Glacial geology and glaciology of the Younger Dryas ice cap in Scotland. 244 pp. Unpublished Ph.D. thesis, University of Edinburgh.

Golledge, N.R. 2010a: Glaciation of Scotland during the Younger Dryas Stadial: a review. Journal of Quaternary Science 25, 550-566.

Golledge, N.R. 2010b: High resolution numerical modelling of the NW Highlands icefields during the Younger Dryas. In Lukas, S. \& Bradwell, T. (eds): The Quaternary of Western Sutherland and adjacent areas: Field Guide, 65-72. Quaternary Research Association, London.

Golledge, N.R., Fabel, D., Everest, J.D., Freeman, S. \& Binnie, S. 2007: First cosmogenic 10Be age constraint on the timing of Younger Dryas glaciation and ice cap thickness, western Scottish Highlands. Journal of Quaternary Science 22, 785-791.

Golledge, N.R., Hubbard, A.L. \& Sugden, D.E. 2008: High-resolution numerical simulation of Younger Dryas glaciation in Scotland. Quaternary Science Reviews 27, 888-904.

Golledge, N.R., Hubbard, A.L. \& Sugden, D.E. 2009: Mass balance, flow, and subglacial processes of a modelled Younger Dryas ice cap in Scotland. Journal of Glaciology 55, 32-42.

Golledge, N.R., Hubbard, A.L. \& Bradwell, T. 2010: Influence of seasonality on glacier mass balance, and implications for palaeoclimate reconstructions. Climate Dynamics 35, 757-770.

Gordon, J.E. 1993: Cnoc a' Mhoraire. In Gordon, J.E., Sutherland, D.G. (eds.): Quaternary of Scotland, 122-123. Chapman and Hall, London.

Gordon, J.E., Darling, W.G., Whalley, W.B \& Gellatly, A.F. 1987: Glaciers of the Southern Lyngen Peninsula, Norway. In Gardiner, V. (ed.): International Geomorphology, Part II, 743-758. Wiley and Sons, Chichester.

Hättestrand, C., Kolka, V. \& Johansen, N. 2008: Cirque infills in the Khibiny Mountains, Kola Peninsula, Russia - palaeoglaciological interpretations and modern analogues in East Antarctica. Journal of Quaternary Science 23, 165-174.

Hooke, R. Le B. 2005: Principles of glacier mechanics. 429 pp. Cambridge University Press, Cambridge.

Hofmann, H.J., Beer, J., Bonani, G., Von Gunten, H.R., Raman, S., Suter, M., Walker, R.L., Wölfli, W. \& Zimmermann, D. 1987: 10Be: Half-life and AMS-standards. Nuclear Instruments and Methods in Physics Research B 29, 32-36. 
Inn, K.G.W., Raman, S., Coursey, B.M., Fassett, J.D. \& Walker, R.L. 1987: Development of the NBS ${ }^{10} \mathrm{Be} /{ }^{9} \mathrm{Be}$ isotopic standard reference material. Nuclear Instruments and Methods in Physics Research B29, p. 27.

Isarin, R.F.B., Renssen, H. \& Vandenberghe, J. 1998: The impact of the North Atlantic Ocean on the Younger Dryas climate in northwestern and central Europe. Journal of Quaternary Science 13, 447-453.

Kirk W. \& Godwin H. 1963: A late-glacial site at Loch Droma, Ross and Cromarty. Transactions of the Royal Society of Edinburgh 65, 225-249.

Kirk, W., Rice, R.J. \& Synge, F.M. 1966: Deglaciation and vertical displacement of shorelines in Wester and Easter Ross. Transactions of the Institute of British Geographers 39, 65-78.

Kohl, C.P. \& Nishiizumi, K. 1992: Chemical isolation of quartz for measurement of in-situ-produced cosmogenic nuclides. Geochimica et Cosmochimica Acta 56, 3583-3587.

Kuhn, M. 1989: The response of the equilibrium line altitude to climate fluctuations: theory and observations. In Oelemans, J. (ed.): Glacier fluctuations and climate change, 407-417. Kluwer Academic Publishers, Dordrecht.

Lal, D. 1991: Cosmic ray labelling of erosion surfaces: in situ nuclide production rates and erosion models. Earth and Planetary Science Letters 104, 424-439.

Lie, O. \& Paasche, O. 2006: How extreme was northern hemisphere seasonality during the Younger Dryas? Quaternary Science Reviews 25, 404-407.

Lifton, N.A., Bieber, J.W., Clem, J.M., Duldig, M.L., Evenson, P. Humble, J.E. \& Pyle, R. 2005: Addressing solar modulation and long-term uncertainties in scaling in situ cosmogenic nuclide production rates. Earth and Planetary Science Letters 239, 140-161.

Lowe, J.J., Rasmussen, S.O., Björk, S., Hoek, W.Z., Steffensen, J.P., Walker, M.J.C. \& Yu, Z.C. and the INTIMATE group, 2008: Synchronisation of palaeoenvironmental events in the North Atlantic region during the Last Termination: a revised protocol recommended by the INTIMATE group. Quaternary Science Reviews 27, 6-17.

Lukas, S. 2006: Morphostratigraphic principles in glacier reconstruction - a perspective from the British Younger Dryas. Progress in Physical Geography 30, 719-736.

Lukas, S. \& Bradwell, T. 2010: Reconstruction of a Lateglacial (Younger Dryas) mountain icefield in Sutherland, northwestern Scotland, and its palaeoclimatic implications. Journal of Quaternary Science 25, 567-580.

McDougall, D.E. 2001: The geomorphological impact of Loch Lomond (Younger Dryas) Stadial plateau icefields in the central Lake District, northwest England. Journal of Quaternary Science 16, 531-543.

Nesje, A. 2009: Latest Pleistocene and Holocene alpine glacier fluctuations in Scandinavia. Quaternary Science Reviews 28, 2119-2136.

Nishiizumi, K., Winterer, E.L., Kohl, C.P., Klein, J., Middleton, R., Lal, D. \& Arnold, J.R. 1989: Cosmic ray production rates of ${ }^{10} \mathrm{Be}$ and ${ }^{26} \mathrm{Al}$ in quartz from glacially polished rocks. Journal of Geophysical Research $94 \mathrm{~B}$, 17907-17915.

Ohmura, .A, Kasser, P. \& Funk, M. 1992: Climate at the equilibrium line of glaciers. Journal of Glaciology 38, 397-411. 
Osmaston, H.A. 2005: Estimates of glacier equilibrium line altitudes by the Area $x$ Altitude, the Area $x$ Altitude Balance Ratio and the Area $x$ Altitude Balance Index methods and their validation. Quaternary International 138-139, 22-31.

Peach, B.N., Gunn, W., Clough, C.T., Hinxman, L.W., Crampton, C.B. \& Anderson, E.M. 1912: The geology of Ben Wyvis, Carn Chuinneag, Inchbae and the surrounding country. Memoir of the Geological Survey, $189 \mathrm{pp}$. HMSO, Edinburgh.

Peach, B.N., Horne, J., Gunn, W., Clough, C.T. \& Greenly, E. 1913: The geology of the Fannich Mountains and the country around upper Loch Maree and Strath Broom. Memoir of the Geological Survey, 127 pp. HMSO, Edinburgh.

Rea, B.R. 2009: Defining modern day Area-Altitude Balance Ratios (AABRs) and their use in glacier-climate reconstructions. Quaternary Science Reviews 28, 237-248.

Rea, B.R. \& Evans, D.J.A. 2003: Plateau Icefield Landsystems. In Evans, D.J.A. (ed.): Glacial Landsystems, 407431. Arnold, London.

Rea, B.R. \& Evans, D.J.A. 2007: Quantifying climate and glacier mass balance in north Norway during the Younger Dryas. Palaeogeography, Palaeoclimatology, Palaeoecology 246, 307-330.

Reed, W. 1988: The vertical dimensions of the last ice sheet and Late Quaternary glacial events in northern Ross-shire, Scotland. 369 pp. Unpublished Ph.D. thesis, University of St Andrews.

Sissons, J.B. 1974: A Late-glacial ice cap on the central Grampians, Scotland. Transactions of the Institute of British Geographers 62, 95-114.

Sissons, J.B. 1977: The Loch Lomond Readvance in the Northern Mainland of Scotland. In Gray, J.M. \& Lowe, J.J. (eds.): Studies in the Scottish Lateglacial environment, 45-59. Pergamon, Oxford.

Stoker, M.S., Bradwell., T., Howe, J.A., Wilkinson, I.P. \& Mclntyre, K. 2009: Lateglacial ice-cap dynamics in NW Scotland: evidence from the fjords of the Summer Isles region. Quaternary Science Reviews 28, 3161-3184.

Stone, J.O. 2000: Air pressure and cosmogenic isotope production, Journal of Geophysical Research 105 (B10), 753-759.

Stuvier, M. \& Reimer, PJ. 2010: Radiocarbon calibration program Calib Rev 6.0.0: http://radiocarbon.pa.qub.ac.uk/calib/calib.html'

Walker, M.J.C., Ballantyne, C.K., Lowe, J.J. \& Sutherland, D.G. 1988: A reinterpretation of the Lateglacial environmental history of the Isle of Skye, Inner Hebrides, Scotland. Journal of Quaternary Science 3, 135-146.

Witte, H.J.L., Coope, G.R., Lemdahl, G. \& Lowe, J.J. 1998: Regression coefficients of thermal gradients in northwestern Europe during the last glacial-Holocene transition using beetle MCR data. Journal of Quaternary Science 13, 435-445.

Yiou, F. \& Raisbeck, G.M. 1972: Half-life of ${ }^{10}$ Be. Physical Review Letters 29, 372-375. 


\section{Figure captions}

Fig. 1. Regional context. Box (labelled Figs 2, 3, 8, 10, 11) shows location of study area. Mean cosmogenic exposure ages are shown for sites reported in Bradwell et al. (2008), and Ballantyne et al. (2009). All ages are for moraine ridges, except for the age labelled 'BR' by Loch Ewe. Black lines delimit reconstructed ice sheet margins in the vicinity during the early part of Greenland Interstadial-1. Dashed line - Bradwell et al. (2008); solid line - Ballantyne et al. (2009). The main Western Highland Younger Dryas ice cap is taken from the BRITICE Map (Clark et al. 2004). Hillshaded digital surface model built from Intermap Technologies NEXTMap Britain topographic data. Northwest illumination.

Fig. 2. Topography of study area and previous glacier reconstructions. Locations of subsequent figures are shown. Contours taken from Intermap Technologies NEXTMap Britain topographic data.

Fig. 3. Glacial geomorphology of the Beinn Dearg massif, and immediate surroundings. A1, A2, A3 indicates location of sampling site for cosmogenic exposure dating. Note, 'mature periglacial features' are taken to include: relict bouldery solifluction sheets and lobes, blockfields, and thick talus deposits.

Fig. 4. Field evidence for former glacier configurations: A. Multi-crested moraine ridge complex in the northern tributary to Glen Alladale (locations of samples A1, A2, and A3 are shown). B. Lateral moraine merging with plateau surface on the northern side of Gleann Mor. C. Down-slope limit of talus in the northern corrie of the Mhucarnaich valley, suggesting the minimal height of a former ice surface. D. Abruptly terminating limit of boulder moraines in the west-facing Coire an Lochain Sgeirich.

Fig. 5. Large sediment accumulations with streamlined upper surfaces at the valley head west of Loch Tuath. The sediment is interpreted to have originally banked up against a thinning ice cap margin which pushed into the valley (black arrow). Subsequent ice cap growth and ice flow from local centres of high ground (white arrow) led to smoothing and streamlining of the surface. Black broken line broadly defines the crests of the large sediment mounds.

Fig. 6. Meandering V-shaped valley on the plateau surface of the Beinn Dearg massif, between 600 $\mathrm{m}$ and $750 \mathrm{~m}$ a.s.l. This feature may have a pre-glacial origin. Hill-shaded digital surface model built from Intermap Technologies NEXTMap Britain topographic data. Northwest illumination.

Fig. 7. Palimpsest moraine assemblages in the Ghiuthais valley of the northern Fannich mountains: A. Geomorphological map. B. Photograph taken from point ' $X$ ' on map looking south-eastward. White broken line shows broad, cross-valley moraines. Key as in Figure 3.

Fig. 8. A. Three-dimensional reconstruction of the YD Beinn Dearg ice cap, based on empirical evidence. Note that the reconstruction is derived from the cumulative landform record; it cannot be 
demonstrated that all outlets were at their maximum position simultaneously. Ice surface contours at $50 \mathrm{~m}$ intervals. B. Ice cap reconstruction showing schematic flowlines and sectors used in ELA calculations. ELAs shown are those calculated using the AABR (1.8) method (Table 3).

Fig. 9. Glacier surface elevation and shear stress in Glen Douchary, calculated using the 'Profiler v.2' spreadsheet of Benn \& Hulton (2010).

Fig. 10. Comparison of empirical ice cap reconstruction (red line, this study) with numerical simulation (colour ramp, Golledge et al. (2008)) Note that the numerical simulation was originally run at $500 \mathrm{~m}$ resolution. The output presented here is interpolated to $50 \mathrm{~m}$.

Fig. 11. Reconstruction of palaeo-ice fronts prior to the YD, based on this study.

Fig. 12. Schematic cross section through the Beinn Dearg massif showing proposed ice cap evolution during the Lateglacial period. See text for details. $L D=$ Loch Droma. 


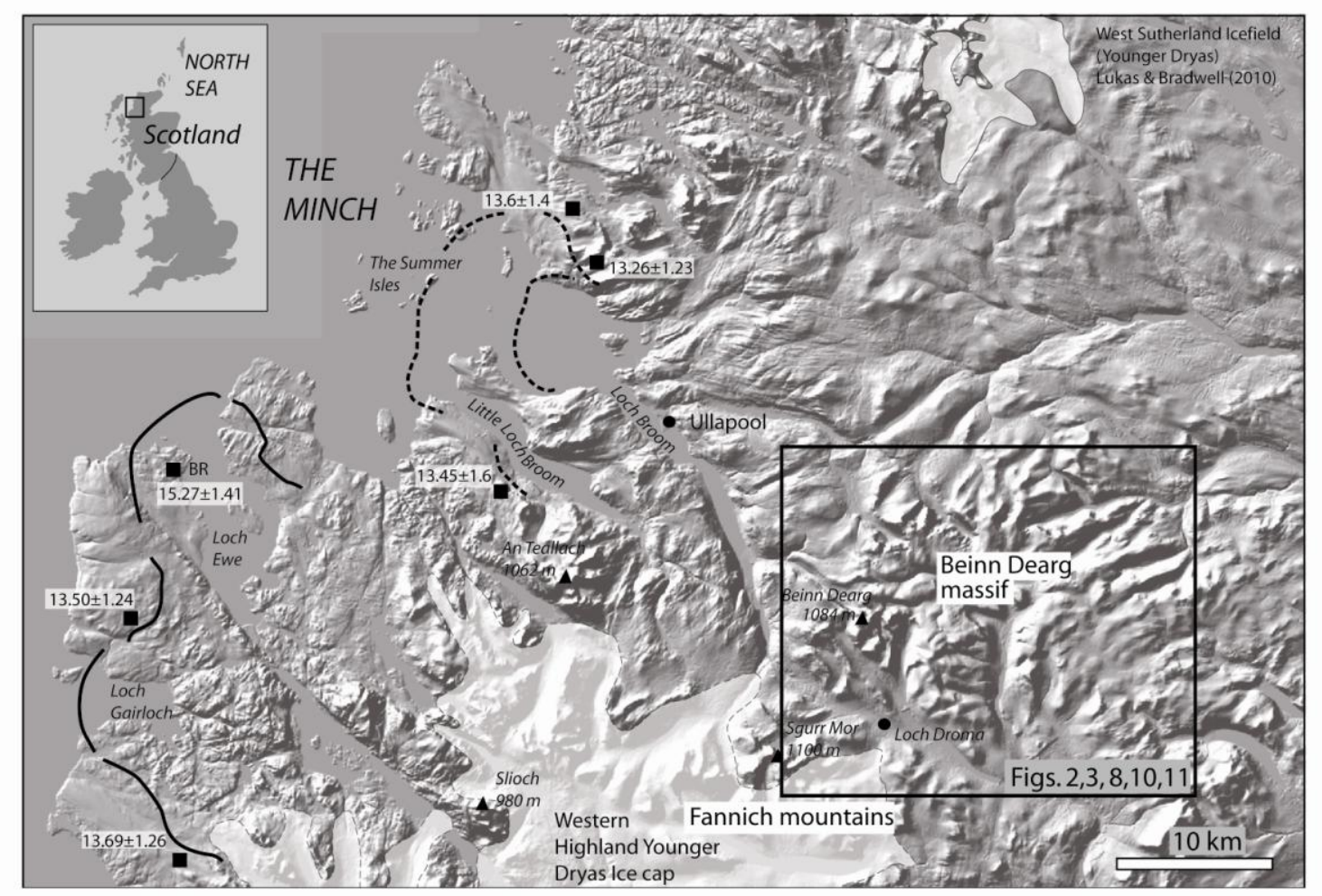

Figure 1.

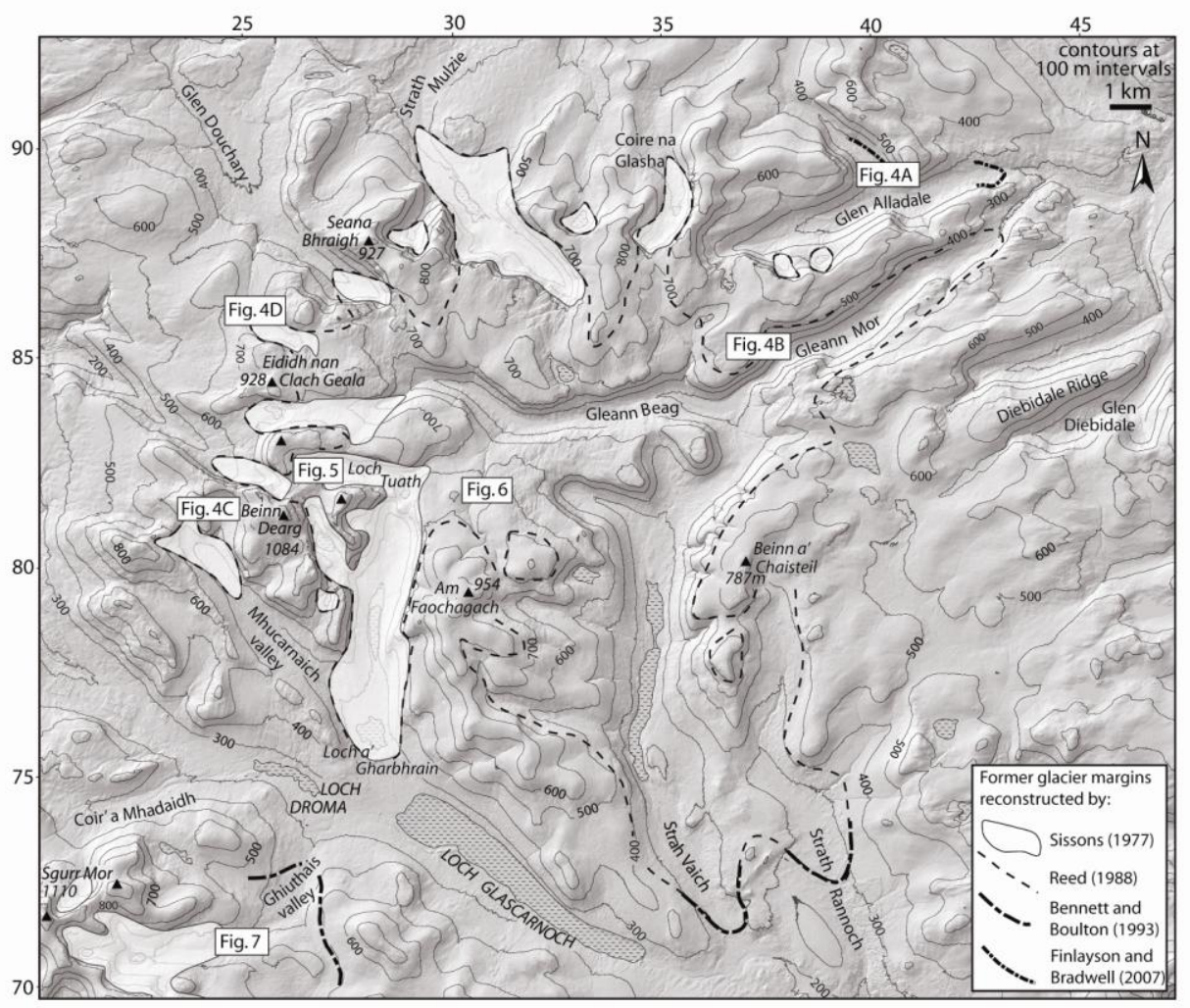

Figure 2. 


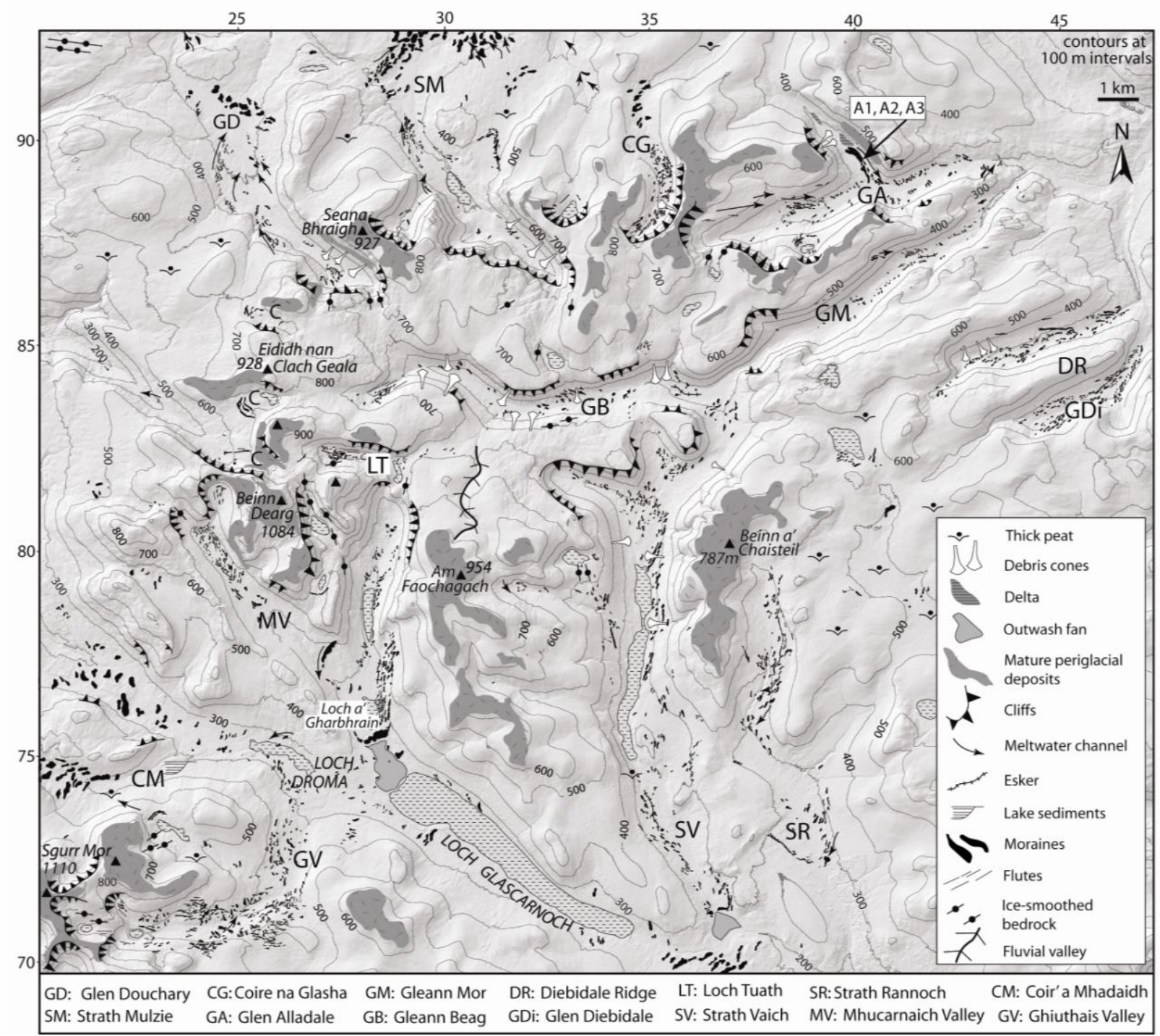

Figure 3. 


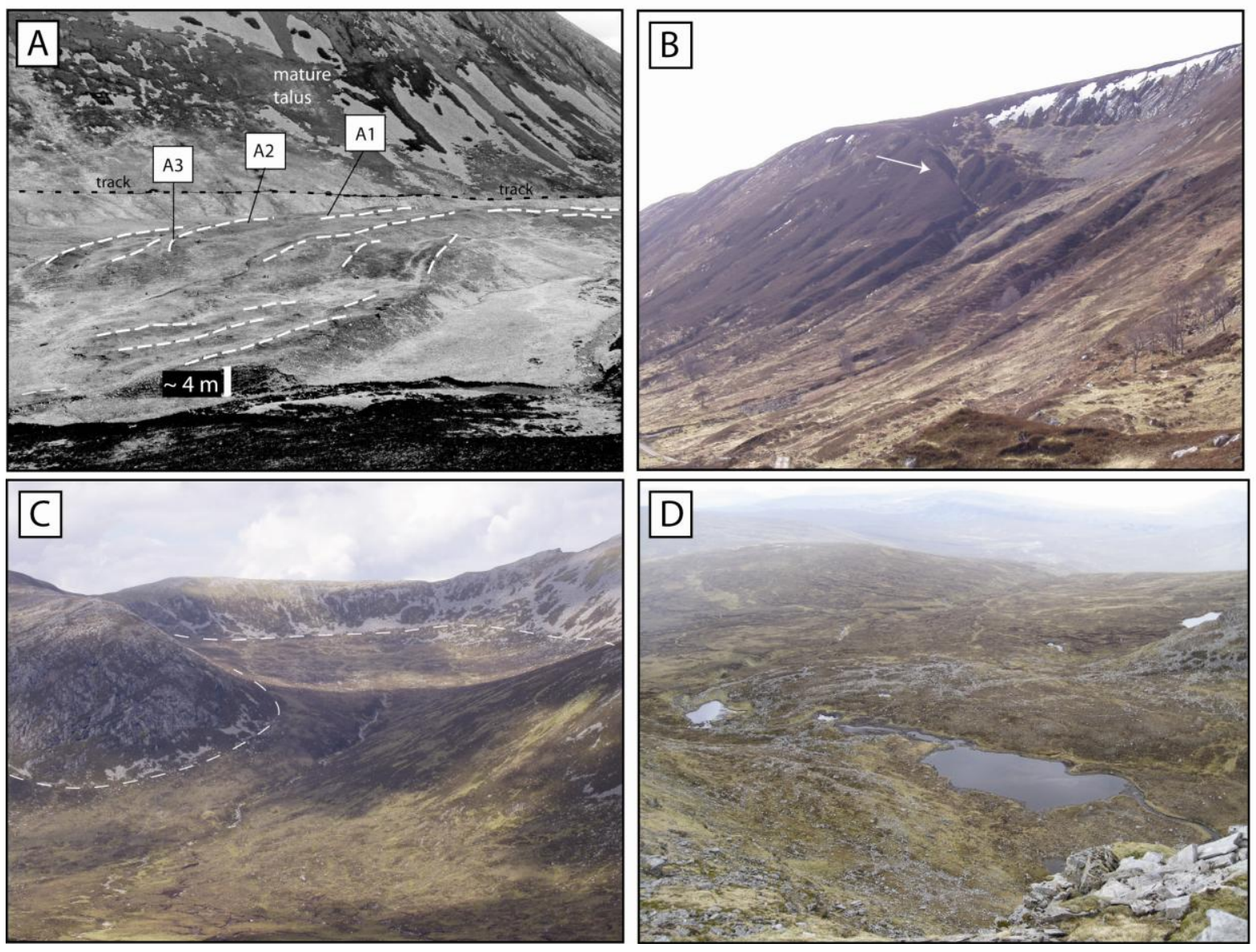

Figure 4. 

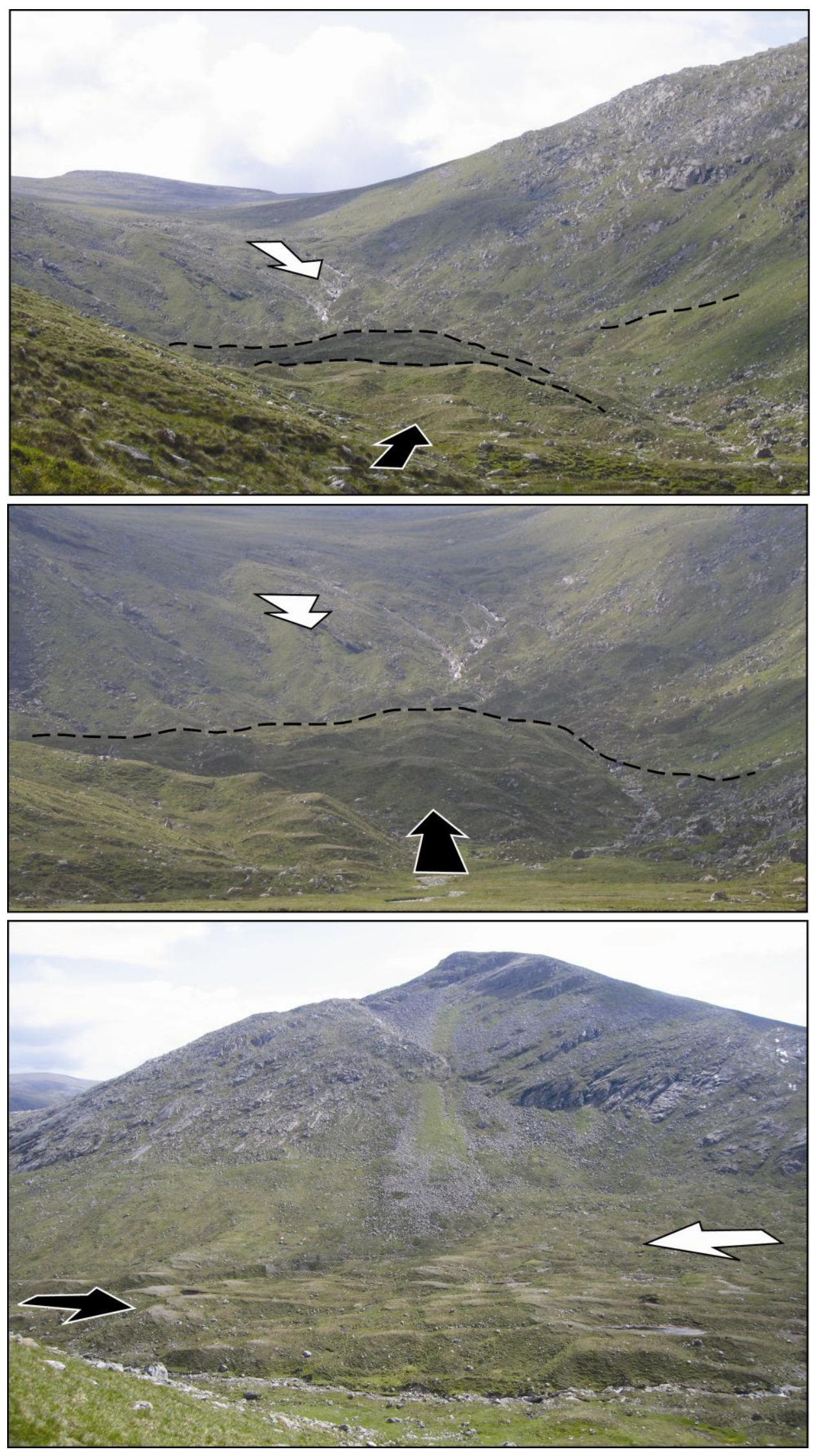

Figure 5. 


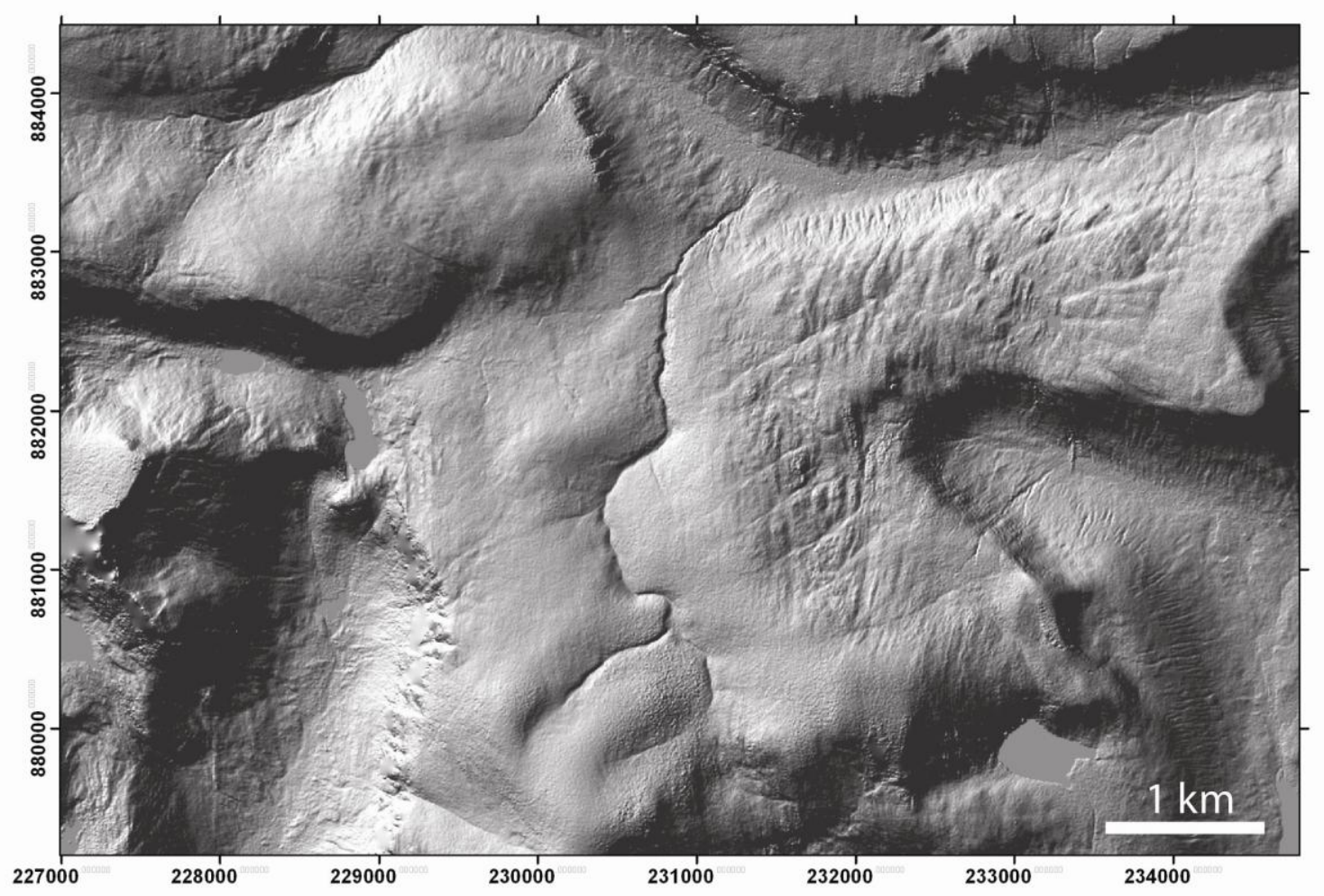

Figure 6. 

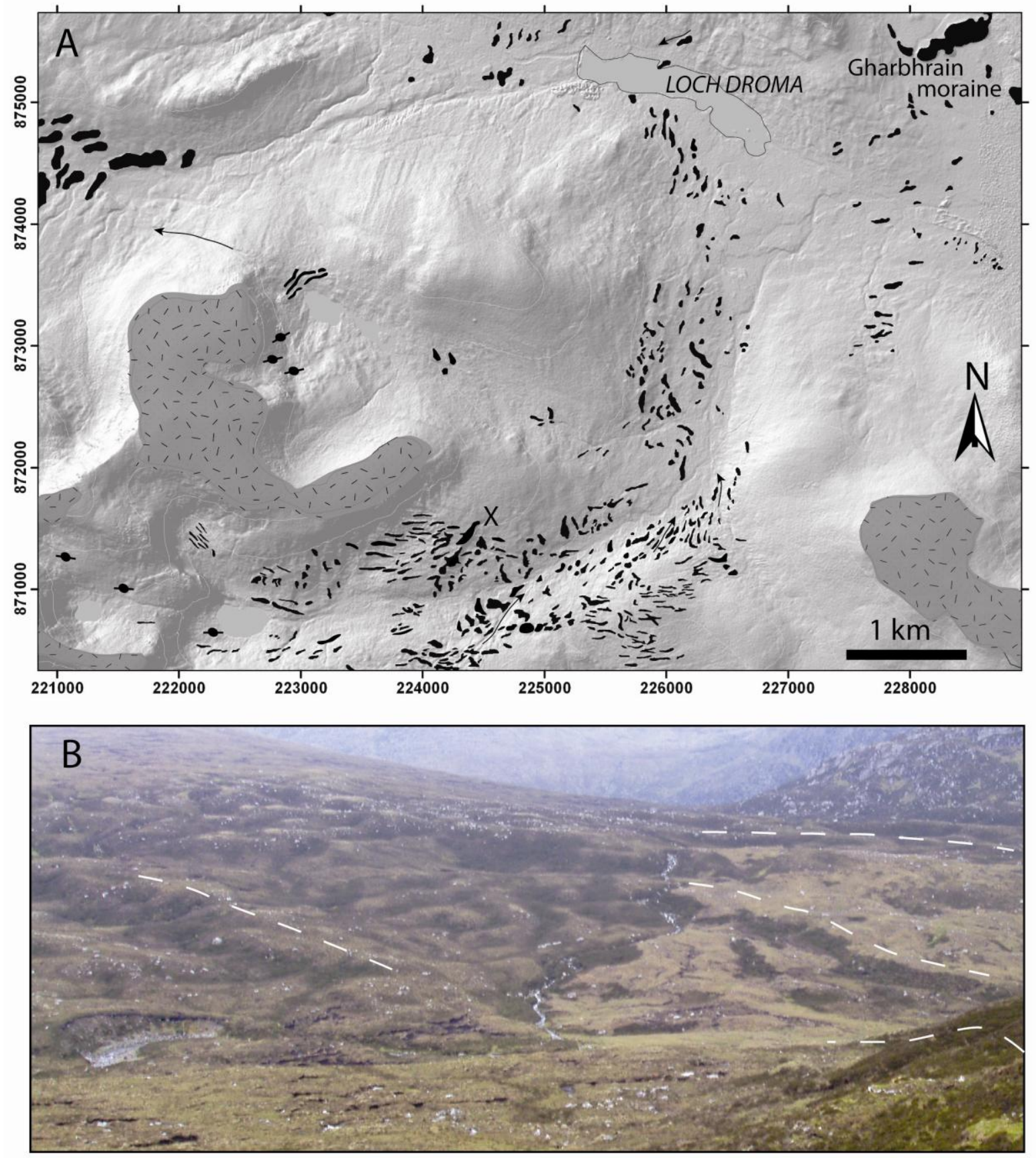

Figure 7. 

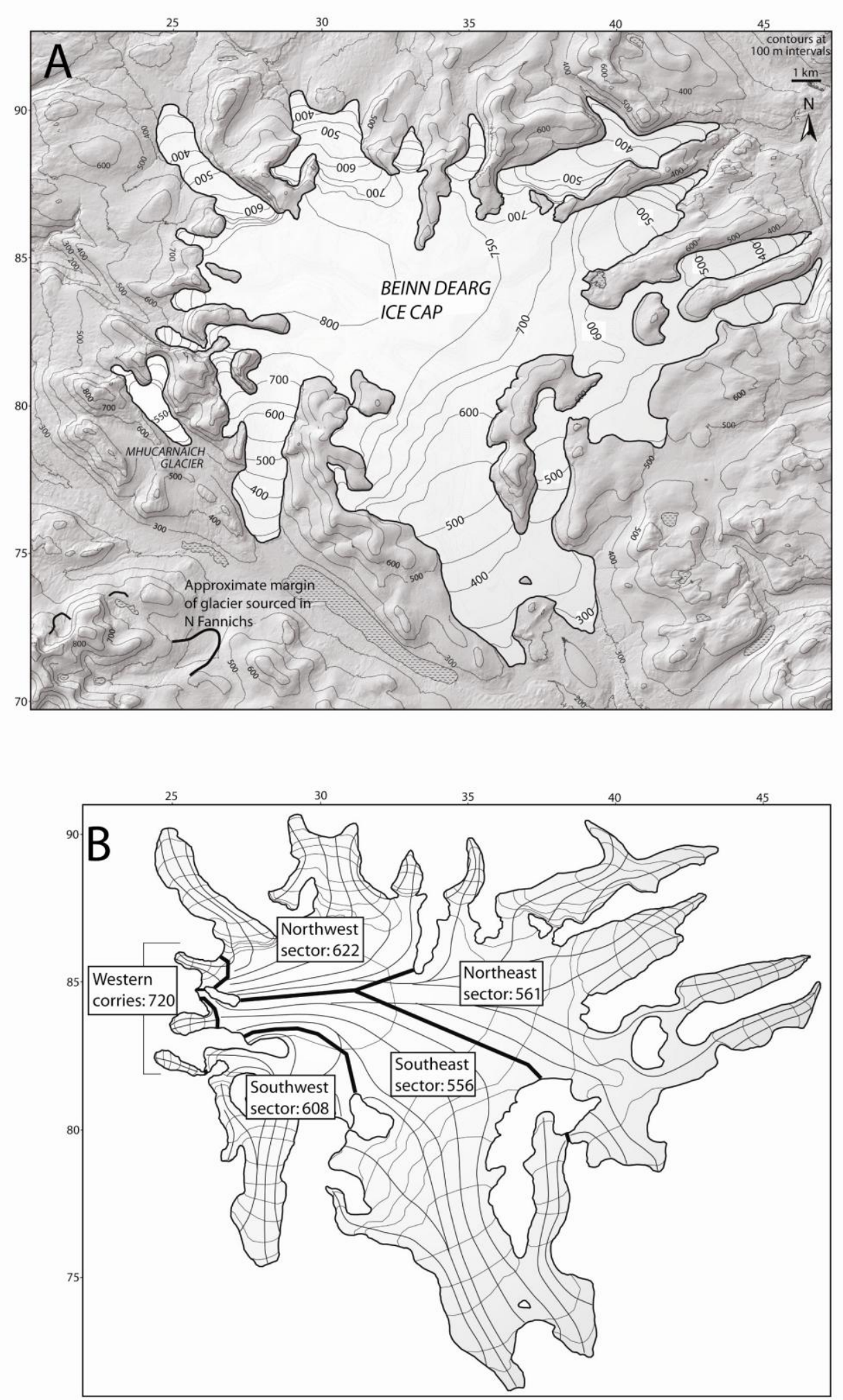

Figure 8. 


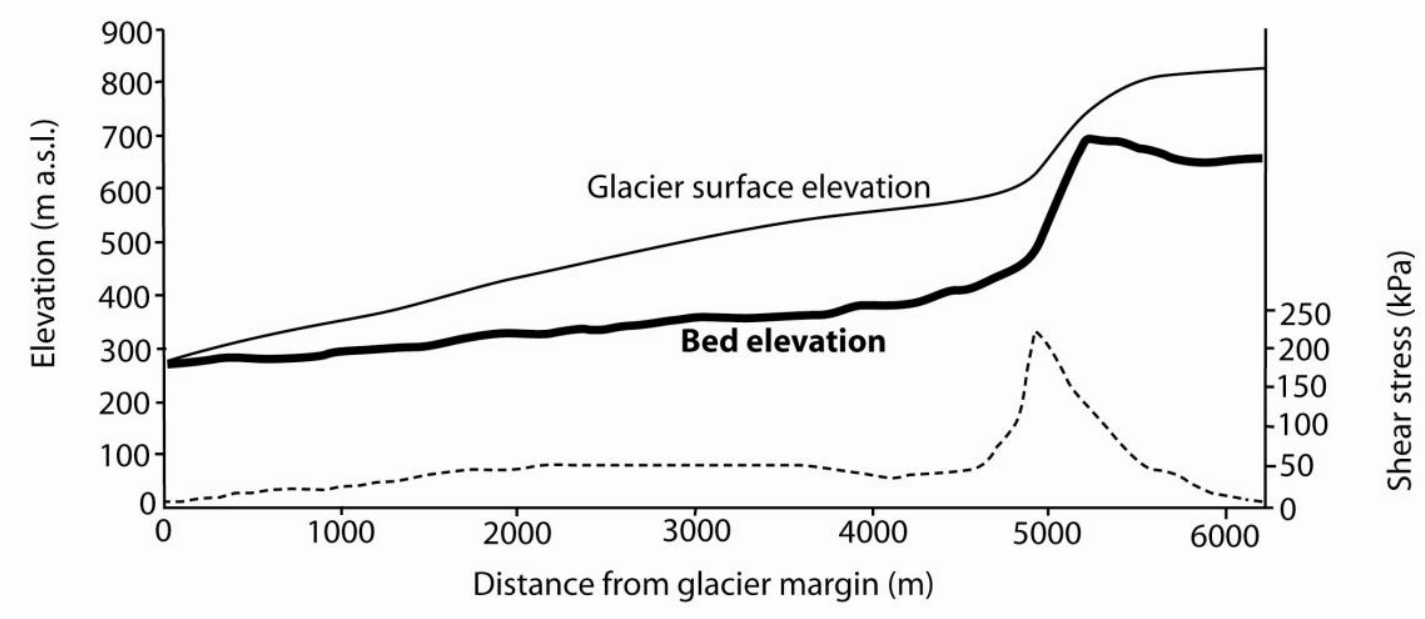

Figure 9.

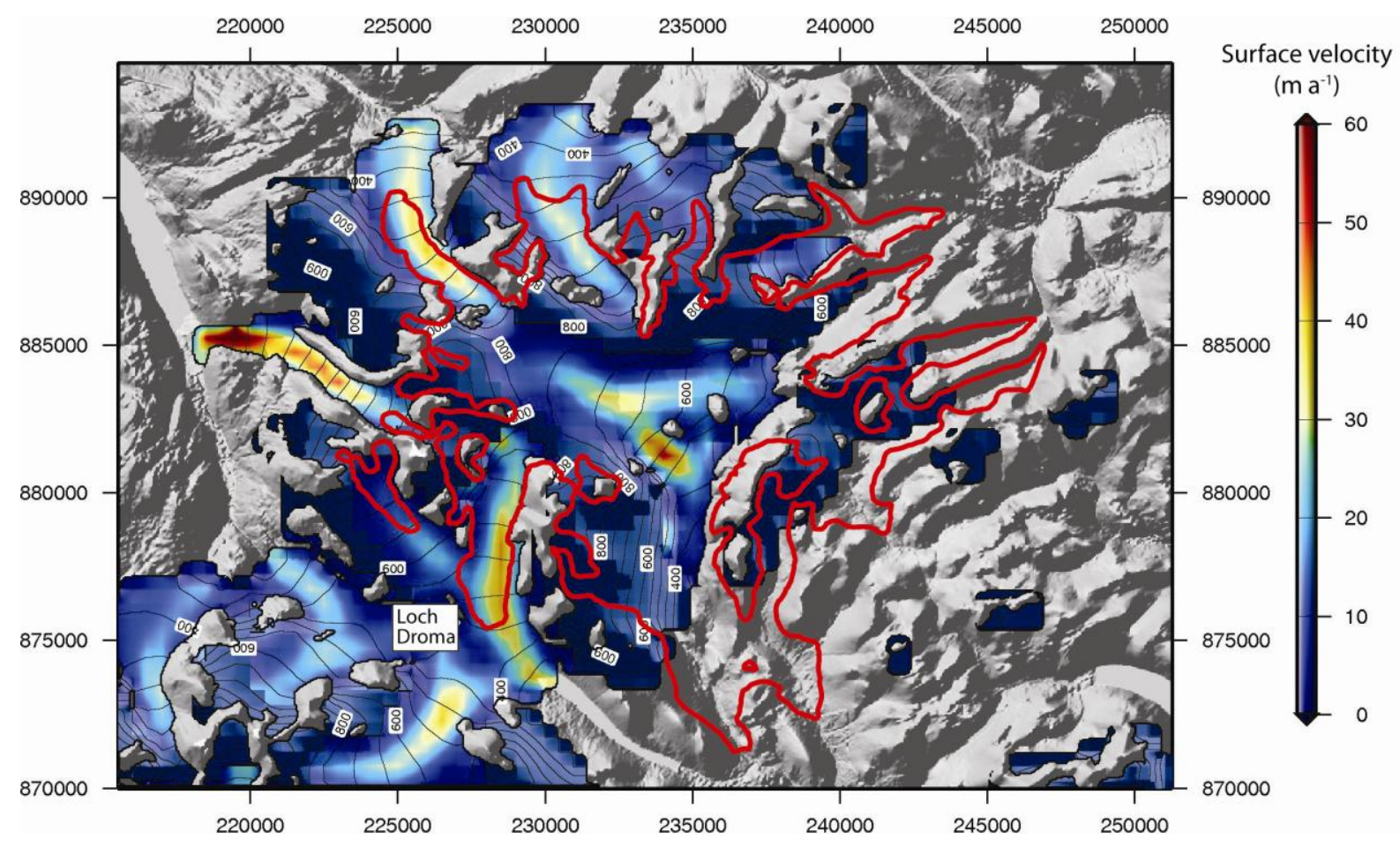

Figure 10. 


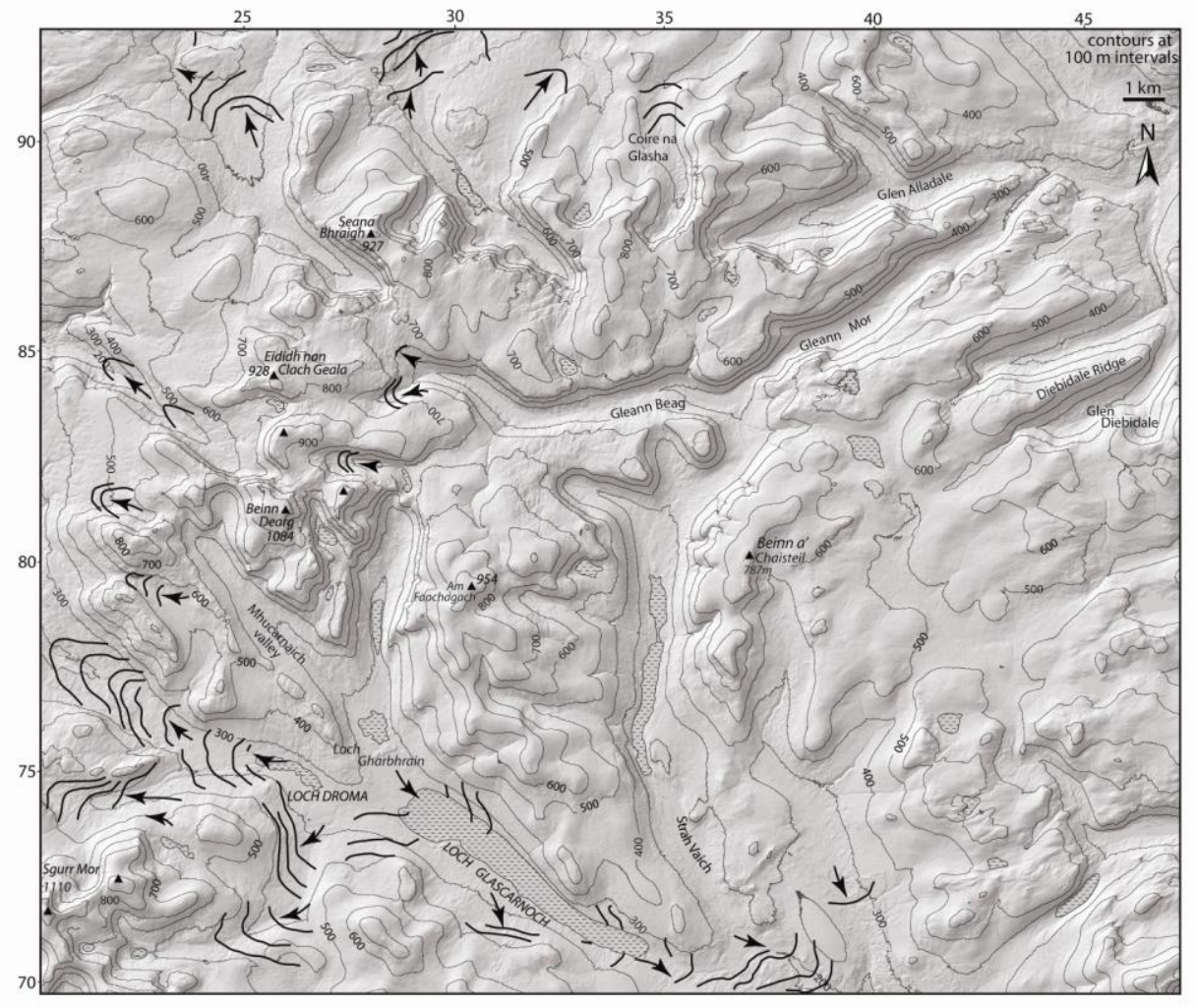

Figure 11. 

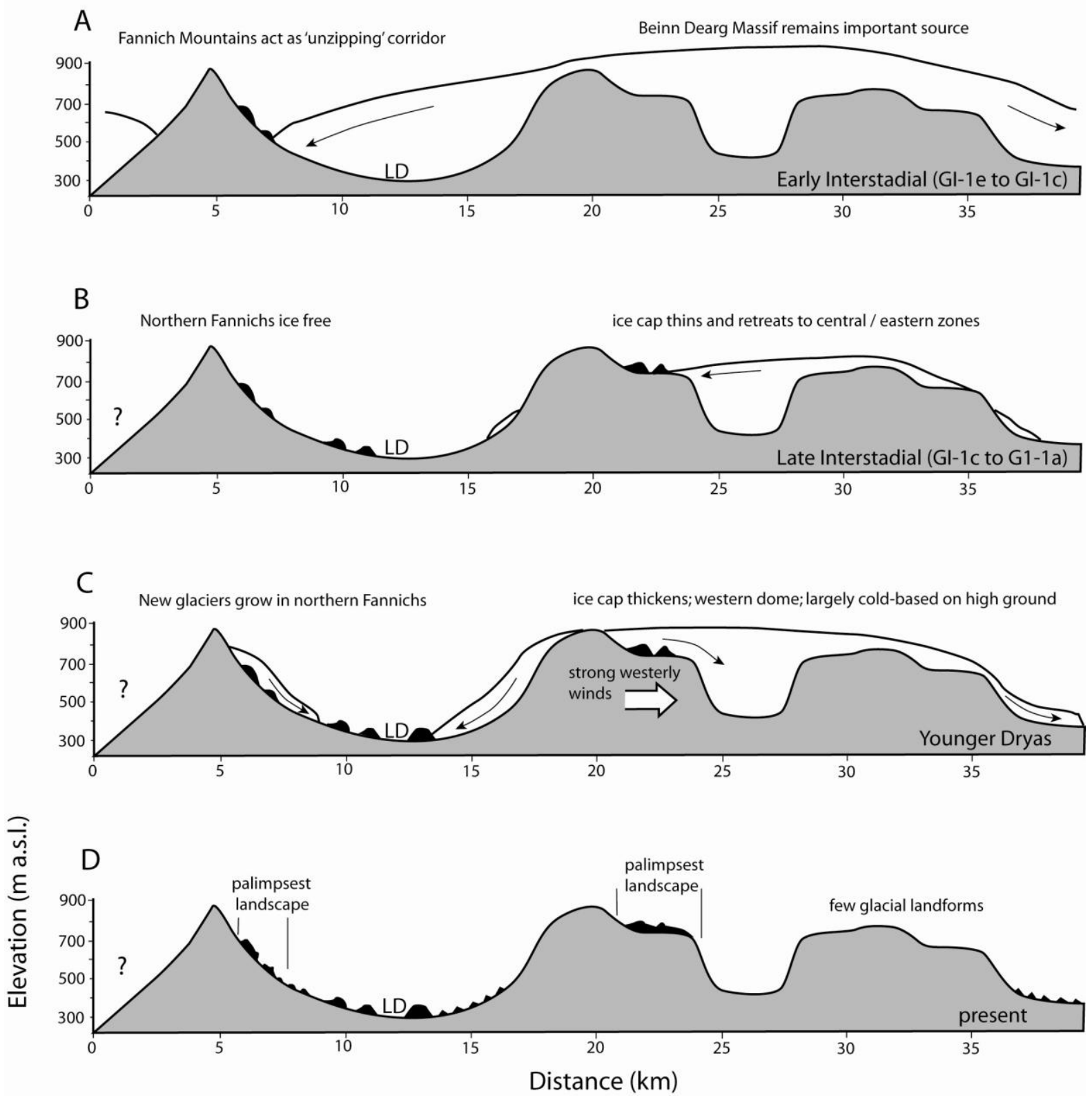

Figure 12. 
Table 1. Sample locations for ${ }^{10} \mathrm{Be}$ exposure dating

\begin{tabular}{|c|c|c|c|c|c|c|c|}
\hline $\begin{array}{c}\text { Sample } \\
\text { (Lab code) }\end{array}$ & Lithology & $\begin{array}{c}\text { Elevation } \\
\text { (m a.s.l.) }\end{array}$ & Lat $\left({ }^{\circ}\right)$ & Long $\left({ }^{\circ}\right)$ & BNG & $\begin{array}{l}\text { Thickness } \\
\text { correction }^{1}\end{array}$ & $\begin{array}{c}\text { Shielding } \\
\text { Factor }^{2}\end{array}$ \\
\hline A1 (b3306) & $\begin{array}{l}\text { gritty } \\
\text { psamite }\end{array}$ & 272 & 57.8683 & -4.7013 & $\begin{array}{l}889795 \\
239865\end{array}$ & 0.9833 & 0.9732 \\
\hline A2 (b3307) & $\begin{array}{c}\text { gritty } \\
\text { psamite }\end{array}$ & 270 & 56.8687 & -4.7017 & $\begin{array}{l}889784 \\
239831\end{array}$ & 0.9833 & 0.9673 \\
\hline A3 (b3085) & vein quartz & 265 & 57.8689 & -4.7029 & $\begin{array}{l}889803 \\
239772\end{array}$ & 0.9833 & 0.9683 \\
\hline
\end{tabular}

${ }^{1}$ Calculated assuming a density of $2.7 \mathrm{~g} \mathrm{~cm}^{-3}$ and attenuation length of $160 \mathrm{~g} \mathrm{~cm}^{-2}$. The tops of all samples were exposed at the surface.

${ }^{2}$ Calculated according to Dunne et al. (1999).

Table 2. Analytical data and exposure ages

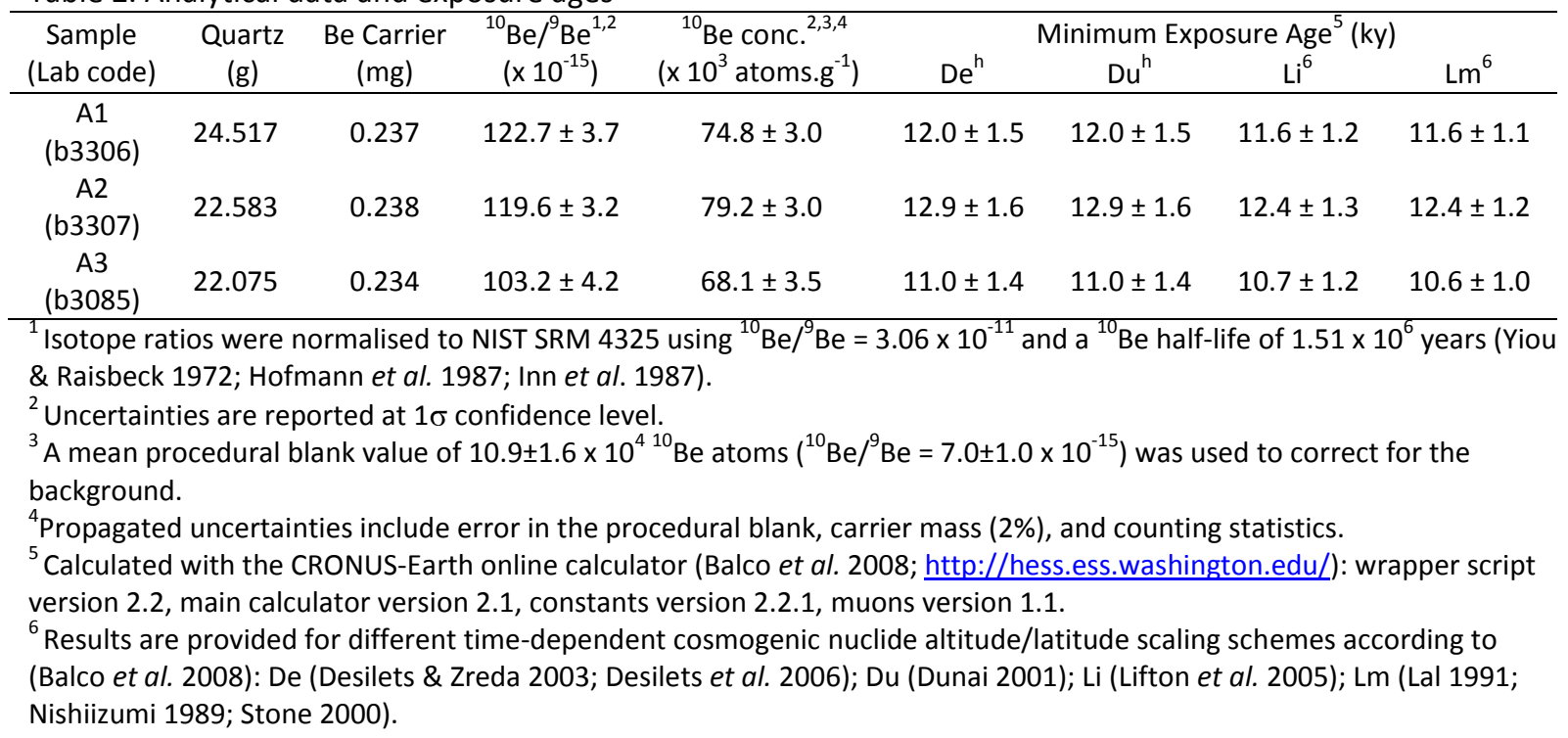


Table 3. Areas and equilibrium line altitudes (ELAs) for the empirically reconstructed YD Beinn Dearg ice cap and independent Mhucarnaich glacier. AWMA = area-weighted mean altitude; $A A R=$ accumulation area ratio; $A A B R=$ area altitude balance ratio. $A A B R$ values calculated using the spreadsheet of Osmaston (2005).

\begin{tabular}{|c|c|c|c|c|c|c|c|}
\hline \multirow[b]{3}{*}{ Ice mass } & \multirow[b]{3}{*}{ Area $\left(\mathrm{km}^{2}\right)$} & \multicolumn{6}{|c|}{ ELA (m a.s.I.) } \\
\hline & & \multirow{2}{*}{ AWMA } & \multicolumn{2}{|c|}{ AAR } & \multicolumn{3}{|c|}{ AABR } \\
\hline & & & 0.5 & 0.6 & 1.67 & 1.8 & 2.0 \\
\hline Western corries & 2.6 & 739 & 720 & 698 & 722 & 720 & 716 \\
\hline Northwest sector & 28.2 & 666 & 725 & 610 & 628 & 622 & 614 \\
\hline Northeast sector & 64.0 & 593 & 560 & 538 & 565 & 561 & 555 \\
\hline Southeast sector & 63.2 & 599 & 575 & 528 & 562 & 556 & 549 \\
\hline Southwest sector & 18.2 & 650 & 700 & 679 & 613 & 608 & 600 \\
\hline Beinn Dearg Icecap & 176.2 & 616.2 & 598 & 548 & 581 & 576 & 569 \\
\hline Mhucarnaich Glacier & 2.74 & 586.9 & 555 & 542 & 570 & 568 & 565 \\
\hline
\end{tabular}

Table 4. Possible ice cap ELA palaeo-precipitation values calculated using equations 1, 2, and 3. An ice cap ELA of $576 \mathrm{~m}(\mathrm{AABR}=1.8)$ is used.

\begin{tabular}{llllllll}
\hline & & \multicolumn{2}{l}{$\begin{array}{l}\text { Golledge et al. (2010): } 30^{\circ} \mathrm{C} \text { annual } \\
\text { temperature range (eq. 2) }\end{array}$} & \multicolumn{2}{l}{$\begin{array}{l}\text { Golledge (2008) : } 10^{\circ} \mathrm{C} \text { annual } \\
\text { temperature range (eq. 3) }\end{array}$} \\
\hline Function & $\begin{array}{l}\text { Ohmura et al. } \\
\text { (1992) (eq. 1) }\end{array}$ & $\begin{array}{l}\text { Summer- } \\
\text { type } P\end{array}$ & $\begin{array}{l}\text { Neutral- } \\
\text { type } P\end{array}$ & $\begin{array}{l}\text { Winter- } \\
\text { type } P\end{array}$ & $\begin{array}{l}\text { Summer- } \\
\text { type } P\end{array}$ & $\begin{array}{l}\text { Neutral- } \\
\text { type } P\end{array}$ & $\begin{array}{l}\text { Winter- } \\
\text { type } P\end{array}$ \\
\hline$P\left(\mathrm{~mm} \mathrm{a}^{-1}\right)$ & 1587 & 1485 & 1061 & 849 & 3184 & 2319 & 1886 \\
\hline
\end{tabular}

Table 5. ELA variations between the empirical reconstruction and numerical simulation $(\Delta \mathrm{h})$, and representative change in winter balance $\left(\delta b_{w}\right)$, winter precipitation, and total precipitation. Note, these calculations carried out based on output from the model of Golledge et al. (2008), assuming a modern annual temperature range (mean July $\mathrm{T}-$ mean Jan $\mathrm{T}=10^{\circ} \mathrm{C}$ ), and neutral precipitation seasonality.

\begin{tabular}{lllllll}
\hline Sector & $\begin{array}{l}\text { Empirically } \\
\text { reconstructed } \\
\text { ELA }(\mathrm{m})\end{array}$ & $\begin{array}{l}\text { Modelled } \\
\text { ELA }(\mathrm{m})\end{array}$ & $\Delta \mathrm{h}(\mathrm{m})$ & $\begin{array}{l}\delta b_{\mathrm{w}} \\
\left(\mathrm{kg} \mathrm{m}^{-2}\right)\end{array}$ & $\begin{array}{l}\text { Proportion } \\
\text { of winter } P \\
(\%)\end{array}$ & $\begin{array}{l}\text { Proportion } \\
\text { of total } P \\
(\%)\end{array}$ \\
\hline Western corries & 720 & 590 & -130 & -492 & -35.9 & -21.2 \\
\hline Northwest sector & 622 & 555 & -67 & -253 & -18.5 & -10.9 \\
\hline Southwest sector & 608 & 600 & -8 & -30 & -2.2 & -1.3 \\
\hline Northeast sector & 561 & 615 & +54 & +204 & +14.9 & +8.8 \\
\hline Southeast sector & 556 & 610 & +54 & +204 & +14.9 & +8.8 \\
\hline
\end{tabular}

